Report of Investigations 97-14a

\title{
GEOLOGIC MAP OF THE EASTERN HALF OF THE MCGRATH QUADRANGLE, ALASKA
}

by

T.K. Bundtzen, E.E. Harris, and W.G. Gilbert

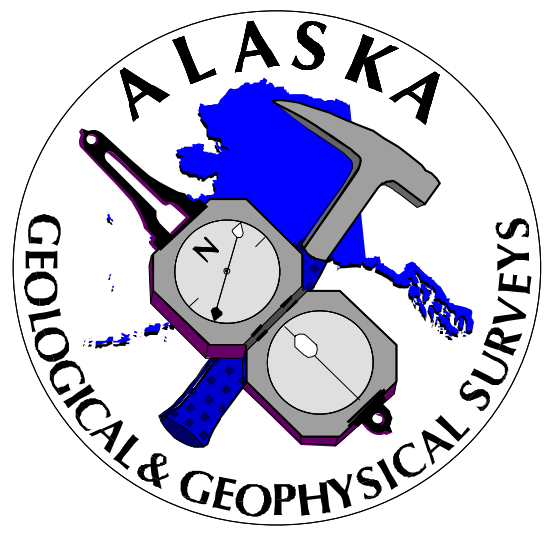

Published by

STATE OF ALASKA

DEPARTMENT OF NATURAL RESOURCES

DIVISION OF GEOLOGICAL \& GEOPHYSICAL SURVEYS 



\title{
STATE OF ALASKA \\ DEPARTMENT OF NATURAL RESOURCES \\ DIVISION OF GEOLOGICAL \& GEOPHYSICAL SURVEYS
}

\author{
Tony Knowles, Govemor \\ John T. Shively, Commissioner \\ Milton A. Wiltse, Director and Srate Geologist
}

1997

This DGGS Report of Investigations is a final report of scientific research. It has received technical review and may be cited as an agency publication.

Report of Investigations $97-14 a$ GEOLOGIC MAP OF THE EASTERN HALF OF THE MCGRATH QUADRANGLE. ALASKA

by

T.K. Bundtzen, E.E. Harris, and W.G. Gilbert 


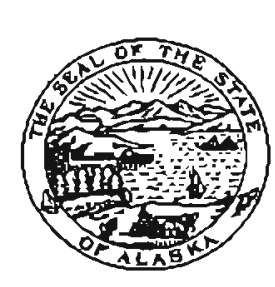

\author{
STATE OF ALASKA \\ Tony Knowles, Governor
}

DEPARTMENT OF NATURAL RESOURCES

John T. Shively, Commissioner

DIVISION OF GEOLOGICAL \& GEOPHYSICAL SURVEYS
Milton A. Wiltse, Director and State Geologist

Division of Geological \& Geophysical Surveys publications can be inspected at the following locations. Address mail orders to the Fairbanks office.

\author{
Alaska Division of Geological \\ \& Geophysical Surveys \\ 794 University Avenue, Suite 200 \\ Fairbanks, Alaska 99709-3645 \\ Elmer E. Rasmuson Library \\ University of Alaska Fairbanks \\ Fairbanks, Alaska 99775-1005
}

\author{
University of Alaska Anchorage Library \\ 3211 Providence Drive \\ Anchorage, Alaska 99508
}

Alaska Resource Library

222 W. 7th Avenue

Anchorage, Alaska 99513-7589

\begin{abstract}
Alaska State Library
State Office Building, 8th Floor

333 Willoughby Avenue

Juneau, A laska 9981 1-0571
\end{abstract}

This publication released by the Division of Geological \& Geophysical Surveys was produced and printed in Fairbanks, Alaska by Dateline Copies at a cost of $\$ 17$ per copy. Publication is required by Alaska Statute 41. "to determine the potential of Alaskan land for production of metals, minerals, fuels, and geothermal resources; the location and supplies of groundwater and construction materials; the potential geologic hazards to buildings, roads, bridges, and other installations and structures; and shall conduct such other surveys and investigations as will advance knowledge of the geology of Alaska." 


\section{CONTENTS}

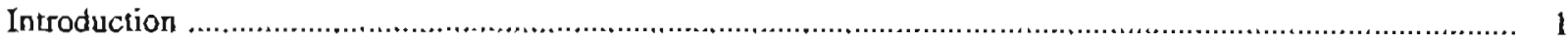

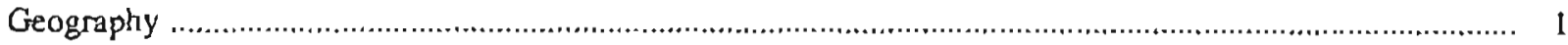

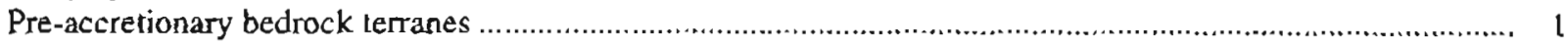

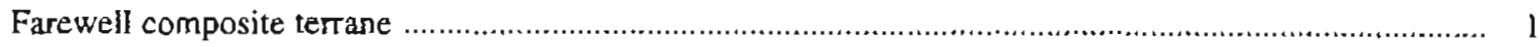

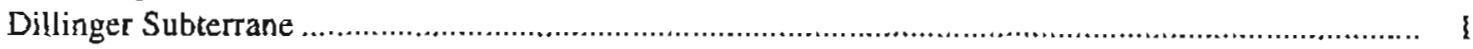

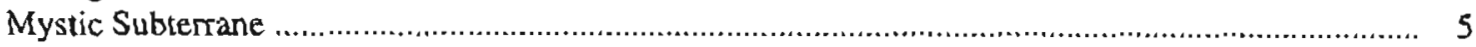

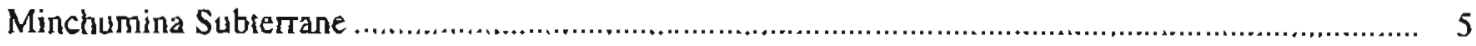

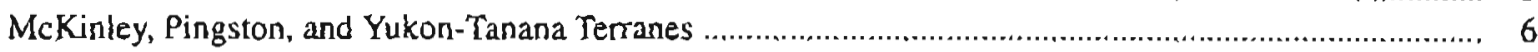

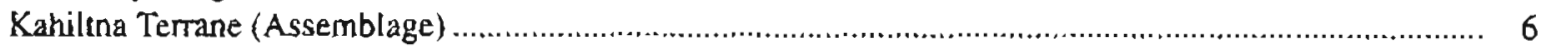

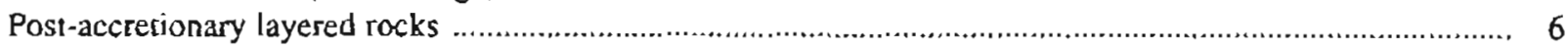

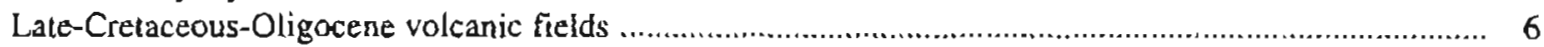

Tertiary and Tertiary-Quaternary Sedimentary Rocks ..................................................................... 7

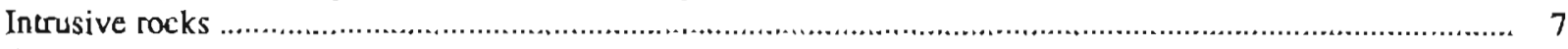

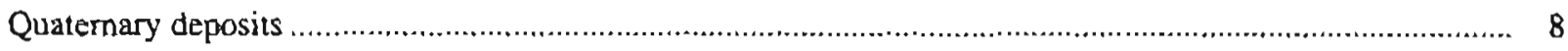

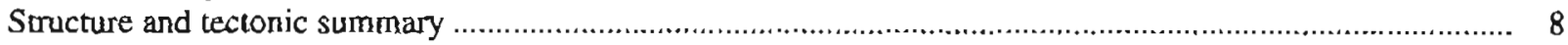

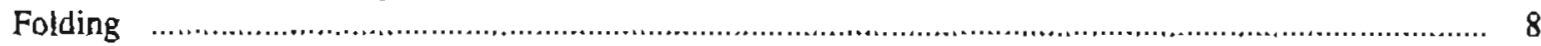

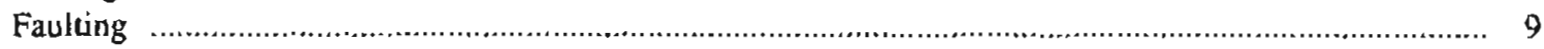

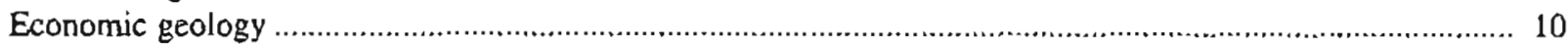

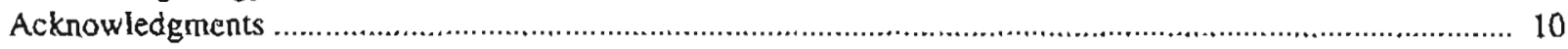

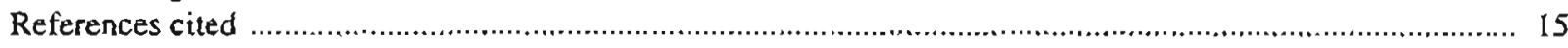

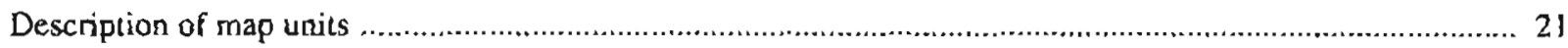

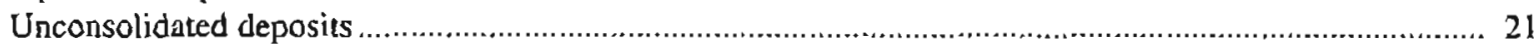

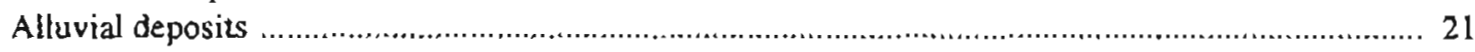

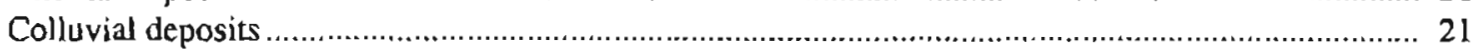

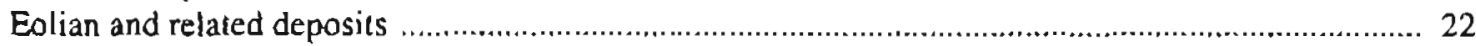

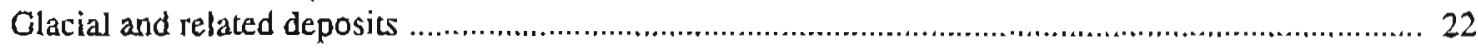

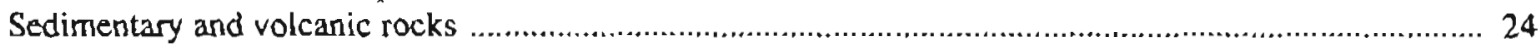

Sheep Creek, Windy Fork and Terra Cotra volcanic fields ...................................................... 24

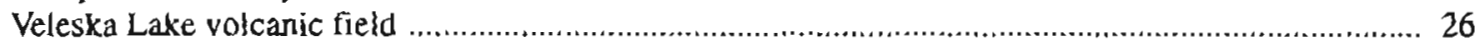

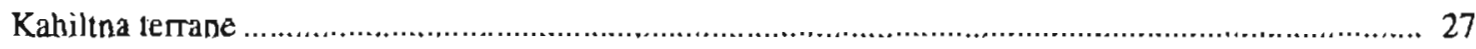

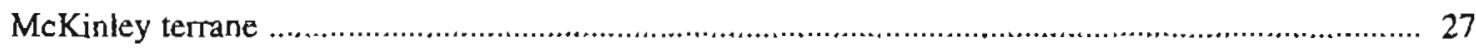

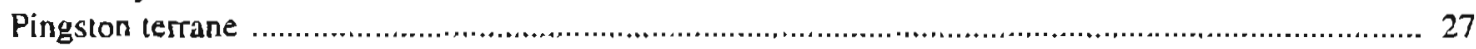

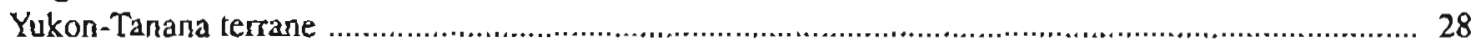

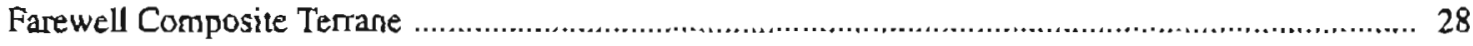

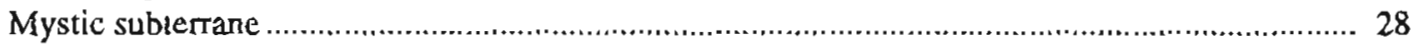

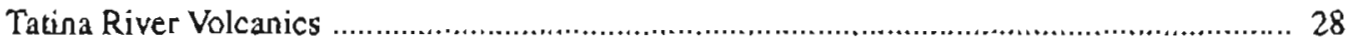

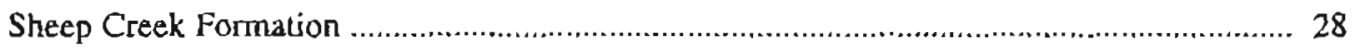

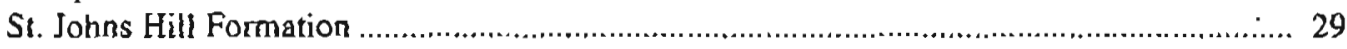

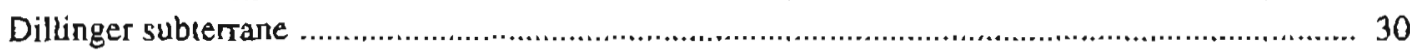

Barren Ridge Limesione ............................................................................................. 30

Terra Cotta Mountains Sandstone ............................................................................. 30

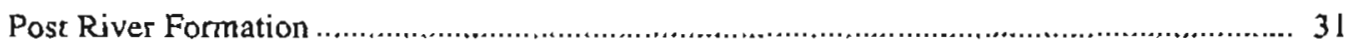

Lyman Hills Formation ......................................................................................... 31

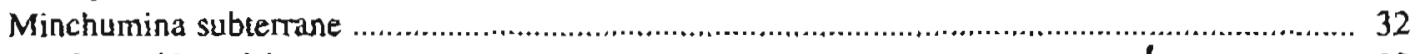

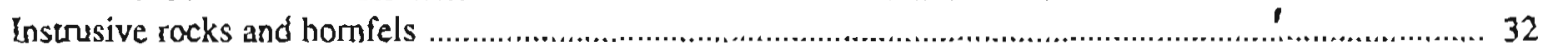

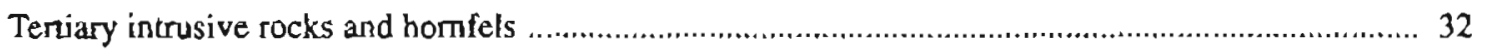

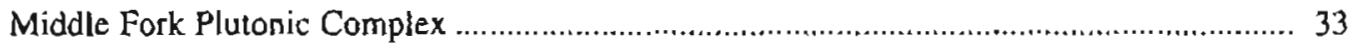

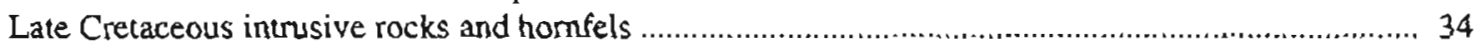

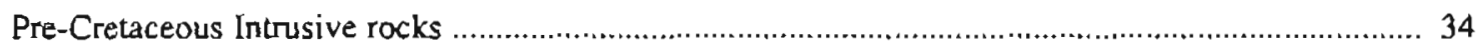




\section{FIGURES}

Figure 1. Index maps showing location and sources ....................................................................... 2

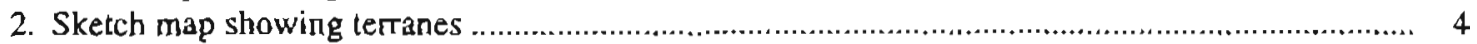

3. Correlation of map units for sheet one .............................................................................. 19

\section{TABLE}

Table 1. Summary of selected metallic mineral deposits and energy resources

\section{SHEET}

[in euvelope]

Sheet 1. Geologic map of the eastem half, McGrath Quadrangle, Alaska. 


\title{
GEOLOGIC MAP OF THE EASTERN HALF OF THE MCGRATH QUADRANGLE, ALASKA
}

\author{
by \\ T.K. Bundtzen,' E.E. Harris. ${ }^{1}$ and W.G. Gilbert ${ }^{2}$
}

\section{INTRODUCTION}

This geological synthesis of the eastem McGrath Quadrangle summarizes systematic 1:63,360-scale geologic mapping conducted by the Alaska Division of Geological and Geophysical Surveys (DGGS) from 1980 to 1989 (sheet 1). Geological maps of the McGrath C-1 (Kline and ochers, 1986). McGrath B-1 (Bundizen and others, 1997a), McGrath B-2 (Bundizen and others, 1982), McGrath B-3 (Gilbert and others, 1990), McGrath A-1 (Bundtzen and others, 1997b), McGrath A-2 (Bundtzen and others, 1987), and McGrath A-3 (Gilbert and others. 1988) quadrangles were combined and compiled at $1: 125,000$ scale (fig. 1). We have completed photo-isterpretation of Quaternary deposits on the piedmont norh of the Alaska Range mountain front, and added unpublished bedrock information from the McGrath B-2, C-2 and $\mathrm{D}-1$ quadrangles.

The geologic map synthesis has also benefited from regional surficial geologic investigations by Fernald (1960) and Kline and Bundtzen (1986), from regional geologic mapping by Reed and Lanphere (1972) and Reed and Nelson (1980). and from detailed mapping in the Windy Fork area (Herreid, 1968) and Terra Cotra Mountains (Churkin and Caner, 1996).

\section{GEOGRAPHY}

The eastem McGrath Quadrangle lies roughly astride the boundary between the steep, glacially-carved peaks of the Alaska Range-Southem region on the south, and the northwest-sloping piedmont of the TananaKuskokwim Lowland on the north (Wahrhaftig. 1965). The Denali-Farewell high-angle fault system, which exhibits evidence of active (Holocene) movement in the srudy area, forms this abrupt boundary (sheet 1). The map area is drained by the northerly flowing South, Windy, Middle, and Big Salmon Forks of the Kuskokwim River and smaller tributary sureams. Elevations range from approximately $400 \mathrm{ft}(122 \mathrm{~m})$ on lower South Fork in the McGrath D-3 Quadrangle to an unnamed $7.880 \mathrm{ft}$ $(2,402 \mathrm{~m})$ peak in the west-central McGrath A-2 Quadrangle. Small glaciers occupy cirques and cap the highest

\footnotetext{
'Alaska Division of Geological \& Geophysical Surveys, 794 Univer sity Avenue, Suite 200. Fairbanks, A laska 99709-3645.

${ }^{2}$ Altar Resources Inc.. P.O. Box 42831, Tucson. Avizona 85733.
}

mountain massifs in the Windy Fork and Dillinger River drainages.

The map area contains no maintained roads; however, a 5,580 $\mathrm{ft}(1.700 \mathrm{~m})$ long gravel airstrip is seasonally operative at the former Fanewell Federal Aviation Administration (FAA) station immediately north of the mountain front. Smaller private airstrips throughout the map area could be used in emergencies. The historic Iditarod Trail diagonally crosses the map area for about $120 \mathrm{mi}(190 \mathrm{~km})$ from Happy Valley near Rainy Pass northwestward to lower South Fork.

\section{PRE-ACCRETIONARY BEDROCK TERRANES}

A geologic sketch of the map area is depicted in figure 2. Bedrock units in the eastem McGrath Quadrangle range in age from Late Proterozoic (?) to Pliocene (fig.3; sheet 1). Most layered rock units were originally described by Brooks (1911) as the Tatina Group, after exposures on the Tatina River in the Eastern McGrath Quadrangle. The predominantly Paleozoic and Mesozoic rocks exposed io the map area have been considered to be the YukonTanana, Pingsion, Minchumina, and McKinley terranes, which are exposed north of the Denali-Farewell Fault, and the Dillinger. Mystic, and Kahiltna terranes, which are exposed mainly south of the Denali-Farewell Fault. Jones and Silberling (1979) and Jones and others (1983. 1986) described all of them as discrete, fault-bounded, tectono-stratigraphic terranes. Decker and others (1994) and Plafker and Berg (1994) combined the Dillinger, Nixon Fork (not exposed in eastem McGrath Quadrangle). Mincbumina, and Mystic terranes into a Farewell cornposite terrane (FCT), and believe all four constitute subterranes that are linked to each other in complex but normal stratigraphic relacionships; the Farewell composite terrane was later dismembered, and individual subteranes are now separated by major strike-slip faults.

\section{FAREWELL COMPOSITÉ TERRANE}

\section{DILLINGER SUBTERRANE}

Churkin and others (1977) first presented graptolitic and stratigraphic information for a Lower Paleozoic rock section in the southern Terra Conta Mountains of the western Alaska Range. Armstrong and others (1977) referred 

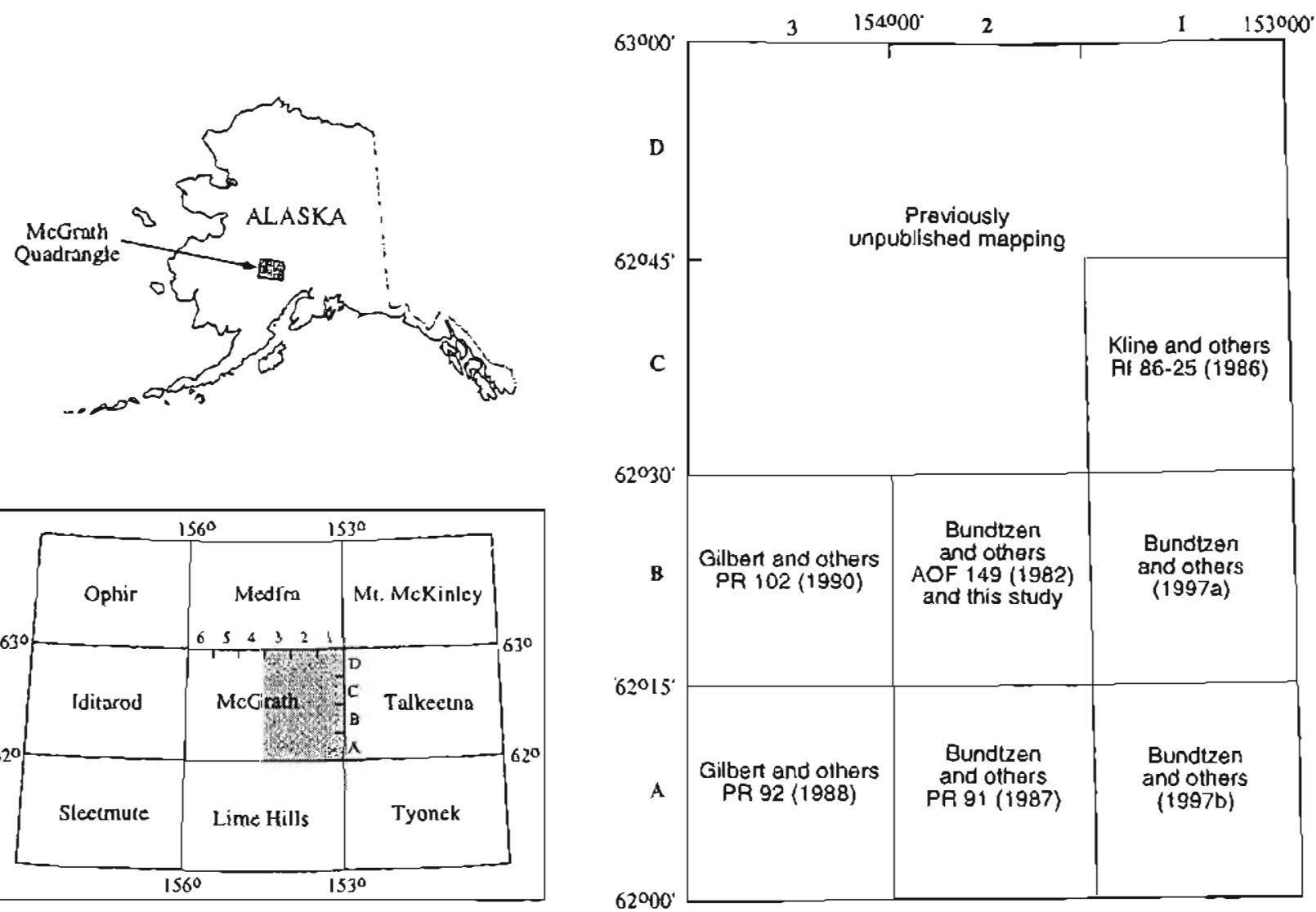

Figure 1. Index maps showing location and sources of 1:63,360-scale mapping for geologic map of the McGrath Quadrangie, eastem half, Alaska. 
to these rocks as "sedimentary rocks of the Dillinger River." Jones and others (1983) used the term "Dillinger Terrane" to describe a coherent. but complexly-folded assemblage of shale, sandstone, and deep water limestones of Ordovician to Devonjan age. For the most part we have adopted the formation nomenclature proposed by Churkin and Carter (1996) for the Dillinger subtertane.

The Dillinger subterrane in the eastern McGrath Quadrangle consists of (1) the Lyman Hills Formation, an Upper Cambrian to Lowest Ordovician (Tremodocian) silty limestone and shale (OCls) containing intraformational gabbro-diorite sills and dikes (MzPzi); (2) the Post River Formation, Lower Ordovician to upper Lower Silurian graptolitic shale, chert, and limestone (SOsh. 1S1); (3) the Terra Cotza Sandstone, mid to Upper Silurian sandstone turbidite. shale, and laminated limestone ( $m S v s, m S s, m S l, u S s l$ ); and (4) the Barren Ridge Limestone. Upper Silurian to Lower Devonian (Pragian Stage) massive laminated limestone, limestone breccia, calcarenite, and calcareous silkstone (DSI). Although we retain the name Post River Formation for Lower Ordovician to upper Lower Silurian graptolitic shales. chert, and limestone, we correlate the "lower siltstone member" of the Post River Formation (Churkin and Carter, 1996) with the top of the Lyman Hills Formation, after a thick sedimentary succession exposed in the Lyman Hills west of the sludy area (Gilbert. 1981; Bundzen and others, 1994).

Bundizen and Gilbert (1983) suggested that the Dillinger subtertane reflects a generally shallowing up. wards, marine regression that includes basinal (Lyman Hills and Post River Formations), turbidite fan (Terra Corta Sandstone), and foreslope (Barren Ridge Limnestone) deposits that were emplaced along a displaced part of the North American continental margin. The Lyman Hills, Post River, and Tera Cotta Sandstone Formations corstain 21 graptolite zones spanning most of the Ordovician and Silurian systems, one of the most complete graptolite successions in the worid (Churkin and Canter. 1996; C. Carter, written commun., 1994; Bundtzen and others, 1994). However, no graptolites from the Ashgillian stage (Late Ordovician) have yet been found.

The Dillinger subterrane in the map area ranges from 6,900 to $9.000 \mathrm{ft}(2,100$ to $2.750 \mathrm{~m})$ thick reflecting the thickening and thinning nature of the Terra Cotta Sandstone. Individual members change little in lithologic character laterally; however, the prominent limestone unit of Wenlockian age (mSl) is thickest north of the Tatina River and nearly disappears in the Middle Fork and the northwestern western parts of the map area. The Post River Formation becomes more chert rich in a northeasterly direction east of South Fork. Most sandstones in the Terra Cotta Sandstone are feldspathic litharenites (Folk, 1968), and show a recycled orogen provenance: however, petrographic analysis of a thin sandstone unit of Werloctian age on Tunis Mountain (mSvs) indicates a volcaniclastic provenance distinct from the bulk of the Silurian turbidite fan.

A facies relationship probably existed between the Dillinger subterrane and the coeval, shallow water dominated carbonate platform lithologies of the Nixon Fork subterrane to the norkh (Bundtzen and Gilbert, 1983; Decker and others, 1994); this suggests that an Upper Cambrian to Lower Devonian shoreline probably existed northwest of the map area. The Terra Cotta Sandstone yields numerous bimodal northeast and southwest paleocurrent measurements (Bundizen and others, 1987: this study), which suggests that current direction paralleled the axis of the continental margin. A progressive increase in carbonate content in younger clastic rocks of the Dillinger subterrane may indicate that carbonate platform deposits, possibly from the Nixon Fork subterrane, supplied increasing amounts of carbonate detritus as the progressively younger Dillinger deposits regressed shoreward.

We note similarities between the Lyman Hills Formation in the study area and the Rabbit Kettle Formation of Upper Cambrian to Lower Ordovician age, which crops out in the Selwyn Basin of Yukon, British Columbia, and Northwest Territories, Canada (Gordey and Anderson, 1993). Diorite and gabbro sills (MzPzi) that intrude the Lyman Hills Formation are distinculy alkaline (Bundtzen and others, 1994), and are similar to alkatic mafic sills that intrude the Rabbit Kettle Formation in northem British Columbia, Canada (Gabrielse, 1963).

The Post River Formation may correlate with the lower and middle Road River Formation, which overlies the Rabbit Ketile and equivalent lithologies in central Yukon Territory, Canada, and east-central Alaska (Gordey and Anderson, 1993).

The Terra Cona Sandstone might be equivalent to calcareous sandy siltsione portions of the upper Road River Fomation in central Yukon, or poorly mapped clastic deposits of mid to Late Silurian age exposed on the "Cassiar Platform" of northern British Columbia (Gabrielse, 1963; Grant Abbott, oral comm., 1996).

The Barren Ridge Limestone is similar to mapped carbonate debris deposits exposed along the westem edge of the Cassiar Platform in British Columbia. Canada (Gabrielse, 1963).

Our speculative correlation of the Dillinger subterrane with coeval rocks in northern Canada implies that up to $950 \mathrm{mi}(1,500 \mathrm{~km})$ of cumulative right-lateral offset was taken up along the Denali-Farewell. Tintina, and related strike-slip faults, accompanied by counter. clockwise sotation of mainland Alaska. The amount of offset is consistent with the scenario suggested by Plafker and Berg (1994), who proposed that the Farewell Composite Terrane originated along the North American continental margin in Cambrian-Devonian time, and subse- 


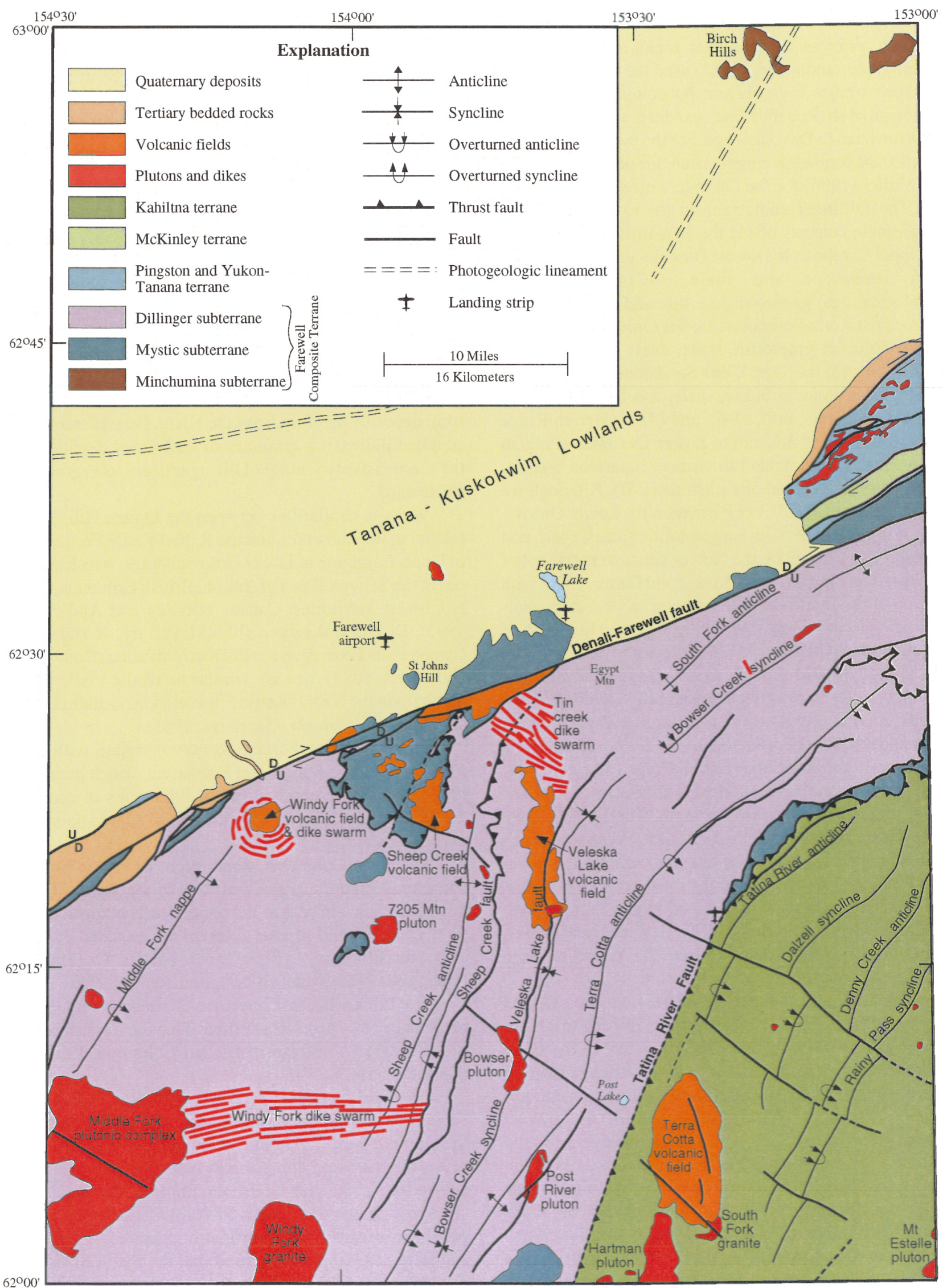

Figure 2. Sketch map showing terranes and subterranes, volcanic fields, plutons, and major structural features of the eastern half of McGrath Quadrangle, Alaska. Modified from geologic map, this report. 
quently moved into its present position in western Alaska during the Mesozoic and Cenozoic.

\section{MYSTIC SUBTERRANE}

The Dillinger subterrane in the eastern McGrath Quadrangle is both stratigraphically and structurally overlain by sublithic clastic rocks. both shallow and deep water limestones, banded cher, and pillow basalt that range in age from the Emsian stage of the Early Devonian to the Sinemurian stage of the Early Jurassic. These rocks were described as the Mystic terrane by Jones and Silberling (1979) after exposures mapped by Reed and Neison (1980) in the Talkeena Quadrangle. South of the DenaliFarewell fault, the base of the Mystic subterrane is the Sheep Creek Formation (PDs), a clastic-dominated section ranging in age from the Eifian stage of the late Early Devonian to Middle (?) Permian. The base of the Sheep Creek Formation south of the Denali-Farewell fault is discontinuously marked by a massive, Amphipora-bearing. aigal limestone (IDI) that overlies the Dillinger terrane. The middle portion of the Sheep Creek Formation is characterized by coarse grained, plant-rich curbidite sandstone, shallow water, calcareous fusilinid-bearing sublithic sandstone of Pennsylvanian-Pemian age, and non-marine, plant rich, pebble conglomerate that contains Middle Pennsylvanian to Middle Permian (?) plant fossils. This latter conglomerate, which is best exposed at the soutlsem boundary of the map area south of Post River, may be correlative with the "Conglomerate of Mount Dall" as described by Reed and Nelson (1980) in the centrat Talkeetna Quadrangle.

Overlying the Sheep Creek Formation are the Tatina River Volcanics, which consist of volcaniclastic sandstone, chert (Trs), olivine-rich pillow basalt (Trab), and volcaniclastic sandstone, phosphatic shale, and chert pebble conglomerace (IJs) that have yielded Upper Triassic and Lower Jurassic pelecypod collections. Fossil evidence for the time interval of Late Pernian to Middle Triassic that separates the Sheep Creek Formation and Takina River Volcanics has not yet been recognized. Chemically, the pillow basalts are quartz-hyperstene-normarive tholeiites.

Pre-Triassic rocks of the Mystic subterrane in the Tatina River area have apparently been removed by low angle faulting probably related to the Tatina Fault, which is part of a $2-\mathrm{km}$-wide suture zone that separates the Kahiltna tertane (assemblage) from the Dillinger and Mystic subterranes.

North of the Denali-Farewe!l fault, the Mystic subretrane consists of laminated and massive micritic limestone and siltstone of Early (?) Devonian and early Late Devonian (Frasnian) age (Dis, uDI) overlain by calcareous clastic lithologies of the Sheep Creek Formation
(PDs), which are in turn overlain by tholeinic pillow basalt (Trab) of the Tatina River Volcanics. The base of the Mystic subternane differs on both sides of the Denali Farewell fault in the eastern McGrath Quadrangle. The prominent section of megafossil-rich Frasnian limestone that flanks Farewell Mountain does not appear on the south side of the fault in the map area. However, carbonate reef deposits of Frasnian age crop out near the base of the Mystic subterrane in the Shellabarger Pass area of the Talkeetna Quadrangle (Reed and Nelson, 1980). The Frasnian section on the south side of the Denali-Farewell fauls in the eastern McGrath Quadrangle is represented by a much thinner section of concretion-rich, conodontbearing limestone and chert. The basal Early (?) Devonian lamirated limestone on St. Johns Hill, which forms the base of the Mystic subcerrane north of the fault, is believed to be a distal deeper water facies of the Amphipora-bearing algal limestone west of Sheep Creek.

We believe that the pillow basalt section exposed north of the Denali-Farewell fault is part of the Mystic subterrane although Kline and others (1986) and Reed and Nelson (1980) consider them to be part of the McKinley terrane. Samples collected during our studies show tholeiitic pillow basalt sections on both sides of the Denali-Farewell fault to be chemically indistinguishable. For example both basalt sections contain copper contents ranging from 250 to $400 \mathrm{ppm}$ and low $\mathrm{K}_{2} \mathrm{O}, \mathrm{Ba}$, and $\mathrm{Rb}$, and high $\mathrm{TiO}_{2}$.

The Mystic subterrane, which reaches a maximum thickness of about 3,100 ft ( $945 \mathrm{~m}$ ), represents less stable tectonic conditions and more diverse local depositional environments than those of the underlying Dillinger subterrane. Facies relationships between individual formations are poorly understood. The existence of tholeiitic pillow basalt of the Tatina River volcanics on top of shallow marine and non-marine deposits of the Sheep Creek Formation is puzzling. Additionally, Early Jurassic clastic rocks that overlie the tholeistic volcanics contain pelecypod-and cephalopod-rich death assemblages that are believed to have formed in shallow water environments. Bundizen and Gibert (1983) suggested that tholeiitic pillow basalt and gabbro sills now assigned to the Tatina River volcanics reflect a continental margin rift. Limited trace element data reported by Reed and Nelson (1980) from Mystic subterrane pillow basalt in the Talkeetna Quadrangle show them to be the ocean floor type (Pearce and Cann, 1973); howéver, associated rocks also indicate subaerial volcanism.

\section{MINCHUMINA SUBTERRANE}

Metaquartzite and calcareous phyllites of the PzpCs unit poorly exposed in the northeast comer of the map area have been assigned to the Telida subremane of the 
Minchumina subterrane, a northeast-trending belt of deep water limestone, cherr, argillite and quartzite of Late Proterozoic (?) and Lower Paleozoic age that extends 188 $\mathrm{mi}(300 \mathrm{~km})$ from the study area into the central Kantishna River Quadrangle (Patton and others, 1994). Decker and others (1994) and Patton and others (1994) interpret the Minchumina subterrane to be part of an extensive, but discontinuous, deep water continental margin facies that is, in part, coeval with the Nixon Fork subterrane, and are perhaps low-grade metamorphic equivalents to the Dillinger subterrane.

\section{MCKINLEY, PINGSTON, AND YUKON-TANANA TERRANES}

Three poorly-exposed terranes are structurally juxtaposed against each other north of the Denali-Farewell fault in the northeastem part of the map area. They include siliceous phyllite and meta-chert (uPzc and uPzs) assigned to the Yukon-Tanana terrane (Gilber and Bundtzen, 1984), limestone and shale (Trls) of the Pingston terrane (Gilbert and oxhers, 1984) and slate and phyllite $(\mathrm{KJm})$ of the McKinley terrane (Gilber and others, 1984). Gilbert and Bundrzen (1983) suggested that the Yukon-Tanana, Pingston. and possibly McKinley terranes originated at different positions along a common continental margin defined by the Yukon-Tanana block. This interpretation is reinforced by geologic mapping in the eastem McGrath Quadrangle. Limestone and shale (Trls) of the Pingston terrane and slate (KJm) of the McKinley terrane stratigraphically overlie phyllitic chert and phyllites (uPzc) and volcanogenic phyllite (uPzs) that probably represent a distal manifestation of Mississippian volcanism in the Totatlanika Schist (Gilbert and Bundtzen. 1979). a subdivision of the Yukon-Tanana terrane.

\section{KAHILTNA TERRANE (ASSEMBLAGE)}

A thick, rectonically collapsed, isoclinally folded flysch sequence is structurally juxtaposed against the Mystic subterrane in the southeastern portion of the study area. These rocks are cortelative with the Kahiltna terrane or assemblage, named after exposures in the upper Kahiltna River area of south-central Alaska (Jones and others, 1983). Three units have been mapped on the basis of clast size and sedimentary facies: sandstone and shale ( $\mathrm{KJsh}$ ), coarse sandstone and siltstone (KJs), and conglomerate and sandstone $(\mathrm{KJc})$. The Kahiltna tertane (assemblage) in the map area is at least $15,000 \mathrm{ft}(4,570 \mathrm{~m})$ thick.

Five fossil localities in the eastern McGrath Quadrangle have yielded Neocomian or Hauterivian (Early Cretaceous) pelecypods, the same general age range reported from the "northern Kahiltra assemblage" of Nokleberg and others (1994). About $5 \mathrm{mi}(8 \mathrm{~km})$ south of the mouth of the Tatina River near Rohn Roadhouse, a thin limestone member of the KJsh unit contains abundant Inoceramus prismite beds. of probable Early Cretaceous age. Eakins and others (1978) reported Kimmeridgian (Late Jurassic) pelecypods from Kahilena flysch near Lake Clark about $170 \mathrm{mu}(270 \mathrm{~km})$ to the southwest of the map area.

The Kahiltna terrane (assembiage) in the eastern McGrath Quadrangle includes slope, inner fan, and mid fan environments, and contains north or northwest directed paleocurrent indicators. In the map area, the northem boundary of the Kahiltna terrane (assemblage) with the Mystic subtemane is marked by a profound low-angle fault zone expressed as a l-km-wide zone of intense shearing. According to Nokleberg and others (1994), the southern boundary of the Kahilua terrane (assemblage) formed along the northern edge of the Wrangellia Composite Terrane (WCT) prior to its emplacement along the Alaskan continental margin.

\section{POST-ACCRETIONARY LAYERED ROCKS}

\section{LATE CRETACEOUS-OLIGOCENE VOLCANIC FIELDS}

Four volcanic fields of Late Cretaceous-to-Oligocene age overlie the Kahiltna terrane and Dillinger subterrane mainly south of the Denali-Farewell fault zone; small bodies of probable related younger volcanics also exist north of the Denali-Farewell fault. From oldest to youngest, these are the Late Cretaceous-early Tertiary (65.8 Ma) Veleska Lake volcanic field, the early-to-late Eocene (41.3-48.9 Ma) Sheep Creek volcanic field, and the late Eocene-Oligocene (31.3-41.1 Ma) Terra Cotta and Windy Fork voicanic fields (see Solie and others, 1991, for K-Ar age compilation).

All four fields contain similar morphological, textural, and compositional variations. Hence, although the volcanic fields are spatially and age distinctive, we have depicted the same unit designators in the three mid-Tertiary volcanic fields (see Description of Map Units).

The Veleska Lake volcanic field includes basaltic andesite (TKvm), insermediate and thyolitic air fall tuff (TKvt, TKvf), and dacite flows and dikes (TKvd) that probably formed near a vent system. Numerous, small subvolcanic intrusions and dikes that intrude the Veleska Lake volcanic field could not always be distinguished from compositionally similar extrusive rocks: they are sometimes included into the volcanic units.

The Terra Cotta volcanic field is characterized by massive and lapilli dacite (Tvld, Trd) andesite flows and lapilli tuff (Tva), air fall tuff (Tvt), and vent facies dacite 
(Tvvd) and green tuff and lahar deposits (Tvgt. Tvl) that were probably deposited immediately over a volcanic vent center (see structural cross section D-D', sheet 1)). The Hartman pluton exposed along the south flank of the Terra Colta Volcanics is about the same $\mathrm{K}$-Ar age $(37.9 \mathrm{Ma})$ as those obiained from the Terra Cotta volcanic field (31.3-to-41.1 Ma), suggesting the pluton and volcanic field collectively constitute a coeval volcanic-plutonic complex similar to those exposed in the Kuskokwim Mineral Belt of southwestern Alaska (Bundtzen and Miller, 1997).

The Sheep Creek Volcanic Field contains basalt and basaltic andesite flows ( $T v m$ ) that are successively overlain by andesite lows and lapilli luff (Tva), several cycles of coarse- to fine-grained air fall tuff (Tvt), and finally capped by volcaniciastic and lacustrine sediments ( $T V s$ ). We speculate that the latter sediments were deposited in a crater lake that formed over a volcanic center. The Windy Fork volcanic field has been largely eroded away leaving only a ring dike complex (Tids) and the rool zone of a volcanic center (Tva, Tvf).

Despite some age and compositional differences, rhyolite, dacite, and andesire from the Veleska Lake, Terra Cotta, and Sheep Creek volcanic fields exhibit low $\mathrm{K}_{2} \mathrm{O}$ (1.28-2.73 percent), lack of $\mathrm{Fe}_{2} \mathrm{O}_{3}+\mathrm{FeO}$ enrichment (2.40-6.60 percent), moderate $\mathrm{Al}_{2} \mathrm{O}_{3}$ (13.39-18.27 percent), and low $\mathrm{TiO}_{2}(0.27-0.97$ percent). typical of calcalkaline magmas related to subduction. Moll-Stalcup (1994) suggests that chemical signatures of Late Cretaceous to mid-Tertiary volcanic rocks of central Alaska are related to plate motion and subduction conditions in the Kula and Pacific plates.

Collectively, the Sheep Creek. Windy Fork, and Terra Cotta volcanic fields have a similar age range and similar calc-alkaline compositions 10 those reported in both the Teklanika Formation (Gilbert and others, 1976) and the Mount Galen volcanics (Decker and Gilben, 1978), which form early and middle Terriary volcanic fields in the central Alaska Range about $150 \mathrm{mi}(240 \mathrm{~km})$ northeast of the study area.

\section{TERTIARY AND TERTIARY- QUATERNARY SEDIMENTARY ROCKS}

Poorly exposed Tertiary sedimentary rocks crop out discontinuously along the north nank of the Alaska Range immediately north of the Farewell-Denali fault zone. These include sandstone and shale (Ts), coal-bearing sandstone, shale, and conglomerate ( $\mathrm{Tcg}$ ), felsite conglomerate (Tcf), limestone conglomerate ( $\mathrm{Tcl}$ ), and consolidated till and outwash (QTg). Both the Ts and Tcg units are thought to be part of the Little Tonzona coal field exposed at Linle Tonzona River in the Talkeetna Quadrangle
(Sloan and others, 1979). The coal-bearing section near Windy Fork is 90 percent conglomerate, and contains highiy volatile bituminous $C$ or subbinminous $A$ coal beds up to $20 \mathrm{ft}(6 \mathrm{~m})$ thick (Gilbert and others, 1990). Samples from one coal seam contain yellow amber barren of pollen; however, pollen from Teriary conglomerate in the Windy Fork area yielded Eocene-to-middle Oligocene ages (Atlantic Richfield Company unpublished report, 1980).

Paleocurrent indicators and petrographic data from the Tertiary deposits flanking the front of the Alaska Range in the eastem McGrath Quadrangle (Dickey, 1984) are similar to those in the ceniral Alaska Range adjacent to Nenana River valley (Wahrhaftig and others, 1969; Stevens, 1971). During the Eocene and Oligocene, sediments shed from a metamorphic upland to the north were transported southward across the present-day Alaska Range. On the basis of the southward-directed paleocurrents and similarities of conglomeratic-rich sections in the study area and those in the Susitna Lowland, Wahrhaftig and others (1994) suggested that the Little Tonzona coal field area may be the source region for streams of Eocene to Middle Oligocene age that flowed through the Susitna Lowland to the Cook Inlet Regionobviously prior to the formation of the Alaska Range. A shift to a southerly local source took place in Miocene (?) to Pliocene time ( $\mathrm{TcF}, \mathrm{Tcl}$ ), and volcanic and carbonaterich clasts of local derivation were deposited in an orogenic piedmont environment.

Gravity surveys conducted by the Alaska Department of Natural Resources in 1981 and 1983 (Meyer and Krouskop. 1986; Henring and others, 1984) suggest that much of the piedmont from the Alaska Range mountain front to the Kuskokwim River is underlain by thin to moderately thick Tertiary sedimentary rocks-locally thickened in graben-derived basins.

Tilted, consolidated till and outwash (QTg) that crops out in a thin band near Big Salmon Fork near the eastem boundary of the map is thought to be equivalent to the Pliocene-early Pleistocene Nenana Gravel, an extensive glacio-fluvial deposit overlying the Healy coal bearing group in the central Alaska Range (Wahrhaftig and others, 1969; Thorson, 1986).

\section{INTRUSIVE ROCKS}

The eastern McGrath Quadrangle contains a wide yariety of plutons, dikes and sills that range in age from Lower Paleozoic (?) to Miocene. The oldest are considered to be pre-accretionary in age and include Mesozoic-Paleozoic gabbro-diorite sills (MzPzi), Triassic picrite, ankaramite, and diorite sills (Trum), and Jurassic-Cretaceous gabbro-diorite sills ( $\mathrm{KJg}$ ) that intrude intraformationally into the lower Dillinger and upper 
Mystic subteranes, and Pingston terrane respectively. The Triassic sills (Trum) are believed to be feeders for mafic volcanism in the Tatina River volcanics. The MzPzi and $\mathrm{KJg}$ units probably represent emplacement in rift environments or in surures between terranes. All three suites exhibit tholeiitic and mildly alkaline chemistry (Bundzen and others, 1994: Gilber and others, 1984).

Post accretionary Cretaceous and Teriary plutonic rocks fall into six age groups: (1) Late Cretaceous and possibly earliest Tertiary (67.4-79.0 Ma) gabbro and granodiorite (TKqm, TKm) that intrude the Dillinger subterane and Kahiltna terrane (assemblage) mainly east of South Fork; (2) Paleocene (55.6-57.7 Ma) alkali gabbro to grarite of the Middle Fork plutonic complex (Tgqm, Tgb, Tgsy, and Tsy; Solie, 1983, 1988) and South Fork Granite (Tgr. Bundtzen and others, 1997b); (3) small Paleocene-to-early Eocene (51.1-61.8 Ma) quanz monzonite to quartz porphyry plutons (Tqm): (4) extensive late Paleocene to Eocene (45.5-55.0 Ma) mafic and intermediate dike swarms (Tim); (5) late Eocene (37.6-39.3 Ma) granodiorite and quartz porphyry (Tgd-Hartman pluton and Veleska Lake intrusion); and (6) Oligocene to easly Miocene (20.9-30.1 Ma) trachyandesite-to-basals dike swarms (Tia) and the Windy Fork peralkaline granite (Twg). Solie and others (1991) provided a K-Ar age compilation for the map area.

There appears to be a progressive younging of intrusive rock ages from east to west although we are unsure of the plutonic and tectonic significance of this trend. Most of the plutons exhibit typical reduced and oxidized, metaluminous, calc-alkaline chernistry (Bundizen and others, 1987); however, the Windy Fork granite and Middle Fork plutonic complex are peraluminous and display mildly- to strongly-alkaline character (Solie, 1983, 1988), which implies their origins in one or more highly differenciated, shallow, magma charnbers. Many plutons from the Tertiary suites contain features associated with magmatic stoping, as indicated by extensive intrusive breccias and xenolith development at the Middie Fork plytonic complex, the Bowser Creek pluton, and dike swarms in the Tin Creek-Veleska Lake area.

\section{QUATERNARY DEPOSITS}

About 55 percent of the eastern McGrath Quadrangle is covered by 19 unconsolidated Quaternary units that were deposited in glacisl and glaciofuvial $\{\mathrm{Qg}$, Qrg. Qof. Qdo, Qdot, Qdic, Qdt, Qduf, Qdis, QdtIm, Qdtplm), fluvial (Qa, Qaf. Qat), colluvial (Qca, Qct, Qcl) and eolian (Qe, Qsp) sertings. Quatemary deposits in the many stream valleys of the Alaska Range portion of the siudy area are relatively thin due to the rapid stripping and flushing downstream loward the piedmont slope, where thick accumulations of alluvial fan deposits, outwash fan deposits. and ull are ubiquitous north of the northernmost strand of the Denali-Farewell fault.

Six major periods of glaciation are infered from drift and diamicton in the eastem McGrath Quadrangle (Kline and Bundzen, 1986). Where possible, maximum drift limits are depicted on the map as thick, barbed dashes; Roman numeral designations on the drift limits increase sequentially toward the younger deposits. The oldest glaciations, Big Salmon Fork and pre-Lone Mountain, named after highly modified drift near Big Salmon Fork and north of Lone Mountain, are regarded as late Teriary and Early Pleistocene in age. Drift of the Lone Mountain. Selatna, Farewell I, and Farewell II glaciations are believed to be middle Pleistocene, Mlinoian, early Wisconsin, and late Wisconsin in age. respectively (Fernald, 1960; Kline and Bundtzen, 1986). At least two Selatna, two Farewell I. and four Farewell II stades have been recognized. Unnamed recessional drift limits behind the mountain front are assigned early to late Holocene ages; urifin not assigued to specific glaciations (Qdt) range in age from Wisconsin to Holocene.

Permafrost is discontinuous in Quatemary deposits of the eastern McGrath Quadrangle, and occurs primarily on stopes of northerly aspect and in older deposits on the piedmont slope. Test pits in peaty material overlying Farewell I drift showed that the top of the permafrost is usually about $1 \mathrm{~m}$ below the surface. Peat bogs overlying older Quatemary deposits are frozen nearly from the surface. Active stream channels and some ancestral stream deposits are usually thawed.

\section{STRUCTURE AND TECTONIC SUMMARY}

\section{FOLDING}

North of the Denali-Farewell fault, pre-accretionary rocks were deformed by two or more periods of isoclinal folding; axial surfaces in bedrock outcrops are commonly vertical or near vertical. Pre-mid Cretaceous regional metamorphism recrystallized the Pingston and Yukon-Tanana lithologies to greenschist facies conditions (Gilbert and Bundizen, 1979). Poor exposure limited detailed structural analyses in these rock units. The fold deformation is younger than the Jurassic-Cretaceous deposition of the McKinley terrane, and older shan the emplacement of Cretaceous-Tertiary felsic intrusions (TKf).

South of the Denali-Farewell faulh a strong compressional and low-grade dynamic metamorphic event deformed the pre-accretionary Dillinger and Mystic subterranes, and Kahilma assemblage, producing a series of sub-isoclinal, generally overiurned folds, that range from outcrop to nappe scales (see cross sections, sheet 1). Accompanying the large-scale F1 fold event is a pen- 
etrative axial plane foliation (S1) that is subparallel to the limbs of the folds. Fl folds are superseded by kink bands and related slip cleavage. The axes of many Fl fold strucsures including the Terra Cotta, Sheep Creek, Dalzell, and South Fork anticlines and synclines can be traced for up to $65 \mathrm{mi}(105 \mathrm{~km}$ ) along strike. Many smaller folds that occur on the limbs of the larger fold structures are not depicted in the cross sections. Most sub-isoclinal folds trend $\mathrm{N} 10-40$ degrees east, plunge northeast, and are overrumed ro the nonhwest. However, west of the Sheep Creek fault and east of Windy Fork, fold asymmetry is reversed, and axes plunge to the southwest and the sub-isoclinal folds are overturned to the southeast. The largest fold structure-the Middle Fork anticline (nappe)-exhibits an amplitude of approximately $10 \mathrm{mi}(16 \mathrm{~km})$ in the westem part of the map area (see cross section D-D', sheet 1 ). Collectively the numerous sub-isoclinal folds that deform the Dillinger and Mystic subtertanes and Kahiltna terrane are responsible for an estimated $60 \mathrm{mi}(96 \mathrm{~km})$ of crustal shortening in the eastern McGrath Quadrangle.

The strongly developed $\mathrm{Fl}$ sub-isoclinal folds and related structures in the pre-accretionary terranes south of the Denali-Farewell fault must have taken place after the deposition of the Lower Cretaceous (Hauterivian) Kahiltna terrane fysch and before the emplacement of the oldess dated, early Late Cretaceous (Santonian), nondeforned TKm intrusion (or within the time interval 79-115 Ma). The FI isoclinal folds have been subsequently deformed by an unusual. very large scale kink (see sheel 1) that might be related to a poorly understood period of left-lateral (?) motion along the Denali-Farewell fault system.

After formation of the Sheep Creek volcanic field in Eocene time, the layered rocks were deformed by eastwest to northeast-trending broad open folds with amplitudes ranging from 3 to $12 \mathrm{mi}$ ( 5 to $19 \mathrm{~km}$ ). This later folding episode locally steepened thrust faults and sub-isoclinal folds.

\section{FAULTING}

Thrust faults thought to be synkinematic with the midCretaceous $F 1$ folding event observed in the pre-accretionary rock units have been identified west of South Fork and east of Middle Fork. The boundary between the Dillinger and Mystic subterranes in the Sheep Creek area is thought to be a thrusted unconformity. The Tatina River fault zone, which structurally juxtaposes the Kahiltna terrane and Mystic and Dillinger subterranes, is thought to be a low-angle suture, and is locally mapped as one or more thrust faults.

Younger northeast-trending high-angle faults, including the Sheep Creek fault, cut Paleocene-Eocene dike swarms east of Windy Fork. The north to northeast-trend- ing Veleska Lake fault removed unit uSsl north of Bowser Creek. and disrupted the Dillinger subterrane section in the Tin Creek area; related faults may also control the emplacement of linear north-south oriented early Tertiary plutons, and the Terra Cotta and Veleska Lake volcanic fields.

Northwest-trending high-angle faults cut older Fl folds and northeast-trending high-angle and low-angle faults south of the mountain front. The norhwest-trending high-angle faults contain left lateral offsets of up to $3 \mathrm{mi}(5 \mathrm{~km})$, and vertical displacements of up to $500 \mathrm{ft}$ (152 $\mathrm{m}$ ) as along the south limit of the Sheep Creek volcanic field; however, commonly, very little offset can be determined along the nonhwest-trending high-angte faults of the srudy area. Several structures, including the Bowser Creek and Tin Creek high-angle faults, appear to control emplacement of late Tertiary dikes and plutons related to epigenetic, polymetallic mineralization.

The abrupt mountain front of the eastern McGrath Quadrangle is bounded by the Denali-Farewell fault, a strand of the farger Denali fault system that trends arcuarely across Alaska and Yukon Territory, Canada, for a distance of nearly $1,500 \mathrm{mi}(2,400 \mathrm{~km})$. This faule zone has, in places, broken the piedmont slope and adjacent foothills of the study area into a linear, 5-mile-wide (8-km-wide) zone of horsts and grabens. The active trace of the fault system shifts to a more southerly strand from west 10 east across the eastern McGrath Quadrangle. Regional studies indicate that up to $95 \mathrm{mi}(150 \mathrm{~km})$ of rightlateral slip has taken place along the Denali-Farewell fault in western Alaska and up to $250 \mathrm{mi}(400 \mathrm{~km})$ along the Denali-Mckinley fault in the central Alaska Range (Forbes and others, 1974: Nokleberg and others, 1994). Further to the northeast of the study area in the Mt. McKinley Quadrangle, Reed and Lanphere (1974) demonstrated that the McGonagall and Foraker plutons were originally part of a single igneous mass that was rightlaterally displaced $24 \mathrm{mi}(38 \mathrm{~km})$ along the DenaliMcKinley fault since abour $38 \mathrm{Ma}$. Mystic subterrane rock units occur on both sides of the active strand of the Denali-Farewell fault-suggesting that the more fundamental fault boundary lies noth of the mountain front. and is largely buried under Quaternary deposits. The rapid reduction of right-lateral offset along the larger Denali Fault system from south-central to westem Alaska (250 to $95 \mathrm{mi}$; $40010150 \mathrm{~km}$ ) might be explained by cumulative offsets along multiple fault strands (i.e., as exposed in the northem map area), and by significant stnctural shortening generated by the 79- to 115 -million-year-old sub-isoclinal folding event that deformed pre-accretionary units south of the Denali-Farewe!l fault.

Deformation that folded Oligocene-Eocene coal deposits caused the Denali-Farewell fault to act as a structural buttress. 
Verical offsets in Quaternary units and numerous, recently active fault scarps artest to recent vertical displacement along the Denali-Farewell fault zone that is related to uplift of the Alaska Range. Antecedent dissection of streams that cross horsts contain numerous strath terrace deposits, the oldest of which are tilted by vertical movement along the fault. Furchermore, offset glacial deposits, sag ponds, and fault scarps suggest middle and late Quaternary vertical displacement of up to $100 \mathrm{ft}$ $(30 \mathrm{~m})$ along the Denali-Farewell fault system.

\section{ECONOMIC GEOLOGY}

Mineral production in the map area has been confined to modest aircraft shipments of selected silver-rich base metal skarn deposits at Bowser Creek in the late 1960s (Reed and Elliott, 1968a,b). The Chip-Loi cobaltnickel deposit was briefly explored in the 1960s (Herreid, 1968). A base-metal massive sulfide skarn deposit near Srnith Lake in the McGrath B-2 Quadrangle was explored by a small adit somerime prior to 1980 (Bundtzen and others, 1982). During the 1980s, modern mineral exploration companies looked at metallic mineral potential throughout the "Farewell mineral belt"; however, most firms ceased activities by about 1990. Table I summarizes geologic and geochemical information for 35 selected metallic mineral deposits and energy resources in the eastern McGrath Quadrangle.

The map area contains a variety of polymetallic mineral deposits and energy and industrial mineral resources. Mineral deposir types (after Cox and Singer, 1986) include: (1) numerous copper-magnetite and low-temperature, fracture-controlled lead-zinc-silver-tungsten skam and replacement bodies as at Rat Fork, Ozzna. Tin, Bowser, and Sheep croeks, Smith Lake, and Post River (Bundizen and others, 1982, 1987; Reed and Elliott, 1968a,b: Szumigala, 1987); (2) copper-molybdenum porphyry mineralization at Ozzna Creek; (3) disseminated to massive sulfide nickel-cobalt PGE deposits near Sheep Creek, Middle Fork, Post Lake and at the Chip Loi prospect (Foley and others, 1997; Herreid, 1968; Gilbert and others, 1988: Bundezen and others, 1987); (4) polymetallic veins in the Hartman pluton (Bundtzen and others, 1997b): (5) anomalous uranium, thorium, rare earh elements and semi-precious stones (eudialyte) in the peralkaline Windy Fork pluton and in downstream placer deposits (Reed and Miller, 1980; Gilbert and others, 1988; Gunter and others, 1993): (6) poorly understood, stratiforrt sedimentaryexhalieve (?) pyrite-sphalerite lenses in upper Lower Silurian shale and chert of the Post River Formation (Bundtzen and others, 1982, 1987); and (7) Creede type epithermal (?) precious metal occurrences in the Terra Colta volcanic field.

Although higbly anomalous copper contents (average $=307 \mathrm{ppm}$ ) have been found by Bundtzen and others
(1994) in Late Triassic pillow basalt of the Tatina River volcanics. no significant volcanogenic massive sulfide mineral occurtences have been discovered in the study area. However, the Tatina River volcanics host significant, cupreous, volcanogenic massive sulfide mineralization at Shellabarger Pass in the Talkeerna Quadrangle (Reed and Eberlein, 1972).

Significant coal resources hosted in the Tertiary sedimentary basins flanking the mountain front have been summarized by Solie and Dickey (1982). Construction materials have been described by Kline and Bundzen (1986), Gilbert and others (1988, 1990), and Kline and Pinney (1997). The extensive peat deposits overlying much of the piedmont slope might be suitable for energy or horticultural applications.

During our investigations we noted extensive use by both bison and moose of several mineral licks along the active strand of the Denali-Farewell fault south-southwest of Farewell Lake Lodge.

\section{ACKNOWLEDGMENTS}

This map synthesis was partially suppored by the U.S. Geological Survey's National Mapping Program under cooperative agreement 1434-HQ-96-AG-01471. The conserucisve reviews of Rodney Combellick (DGGS) and Marti L. Miller (U.S. Geological Survey) significantly improved the quality of this report and map product.

Besides the numerous geologists recognized in the mapping efforts (see map credits on sheet 1), we would like to acknowledge Michael Churkin Jr. and the late Bruce Reed for their valuabie insights conceming regional geology of the area. DGGS geologists D.N. Solie and J.T. Kline participated in geologic mapping and made important contributions toward understanding the Middle Fork Plutonic Complex and glaciation in the area, respecively. Regional terrane correlations benefited from cooperative field exchanges with Canadian geologisis Grant Abbor and S.P. Gordey, who have mapped Paleozoic and Mesozoic stratigraphy in northwestern Canada that is similar to rock units in the map area.

In addition we could not have completed the synthesis of the eastem McGrath Quadrangle without the support of many government and private paleontologists: many of whom were former employees of the U. S. Geological Survey. These include Claire Carter and Michael Churkin Jr. (graptolites), R.B. Blodgert and W.A. Oliver (Paleozoic corals and pelecypods), J.W. Miller, N.J. Silberling, and W.P. Elder (Mesozoic pelecypods), R.C. Douglas (fusilinids), C.J. Smiley (Tertiary plant fossils), D.L. Jones and K.M. Reed (radiolaria), and Anita Harris, J.E. Repetski, M.J. Orchard, and Tim Carr (conodonts).

We dedicate this map synthesis and repon to our friend and colleague, the late Jeffrey $T$. Kline. 
Table 1. Summary of selected metallic mineral deposits and energy resources from the Eastern McGrath Quadrangle, Alasku; map numbers keyed to sheet 1

$\begin{array}{cc} & \text { Mineral Deposit } \\ & \text { Type (\#)'; } \\ \text { Name of Deposit } & \text { Principal } \\ & \text { Commodities }\end{array}$

1 Farewell Ungulate Mineral Mineral Licks Licks

2 Windy Fork Subbituminous coal Coal

3 Tin Creek North

4 Tin Creck Midway

5 Unnamed (81BT428429)

6 Unnamed (8IBT549; 89BT316)

7 Tin Creek South

8 Little Bird

9 Post $\# 2$ or Veleska Lake
Copper-iron skam (deposit \#18b); Pb. $\mathrm{Zn.} \mathrm{Cu}, \mathrm{Ag}, \mathrm{Cd}$

Low temperanre $\mathrm{Pb}$ Zn skam (deposit $\# 18 \mathrm{c}$ ): $\mathrm{Pb}, \mathrm{Zn}, \mathrm{Cu}$, $\mathrm{Ag}, \mathrm{Cu}$

Low temperature PbZn skarn (Deposit \#18c): Pb. Cu, Zn, Cd. Ag. Co

Disseminated (Norilsk-like) Cu-NiPGE ? (Deposit \#5b) $\mathrm{Cu}, \mathrm{Ni}, \mathrm{Cr}, \mathrm{Bi}$

Low tempcrature $\mathrm{Pb}$ Zn skam (Deposit \#18c): $\mathrm{Cu}, \mathrm{Pb}, \mathrm{Zn}_{\mathrm{n}}$ Ag. Cd

Polymetallic replacement (Deposit $\# 19 a)$ : W. Cu, Au

Polymetallic replacement (Deposit \$19a); $\mathrm{Cu}, \mathrm{Pb}, \mathrm{Zn}$, Ag

\section{Description and Cited References}

Series of three bicks composed of yellow-brown residual soils: each average 50 $\mathrm{m}$ in diameter in Quatemary drift along 0.6 miles $(1 \mathrm{~km})$ of active strand. Denali-Farewell Fault. Used extensively by buffalo (Bison bison.) and moose (Alces alces). (Bundtzen and others, 1982; this study.)

Contains steeply dipping $201065 \mathrm{ft}(61020 \mathrm{~m})$ coal-shate sections with individual coal beds yielding bru values ranging from 7,587 10 11.742. No resource estimate calculated. (Solie and Dickey. 1982; Dickey, 1984.)

Thin 2 to 6 in ( 5 to $15 \mathrm{~cm}$ ) johannsenite-garnet-sphalerite (blackjack)-galena replacement zones in argillaceous limestone (mSl unit) near $29 \mathrm{Ma}$ granodiorite dike (Tia). Contains up to 2.25 percent $\mathrm{Cu}, \mathrm{L} .21$ percent $\mathrm{Pb}, 0.11$ percent $\mathrm{Zn}$, 0.13 percent $\mathrm{Cd}$, and $319.8 \mathrm{grams} / \mathrm{tonne} \mathrm{Ag}$. (Bunduen and others. 1982; Szumigals, 1987; this study.)

Massive to dissenuinated sphalerite (blackjack), galena, pyrite, pynhotite. and uncornmon arsenopyrite, chalcocite and magncsite in exoskan bodies and sulfide mantos near 25 to $30 \mathrm{Ma}$ granodiorite dike swam; grades of 0.35 percent $\mathrm{Cu}, 0.17$ percen $\mathrm{Pb}, 5.55$ percent $\mathrm{Zn} .0 .05$ percent $\mathrm{Cd}$, and 13 grams/tonne $\mathrm{Ag}$ : at least 352,700 tons (320,000 tonnes) of polymetallic mineralization inferred from Araconda Minerals diamond dill program. (Bunótzen and others, 1982; Szumigala, 1987; Rob Kell, written commun.. 1984.)

Magnetite-diopside-gamel-sulfide skam pods developed in argillaceous limestone (mSI unit) near contact with homblende granodiorite dike. Contains up to 2.30 percent $\mathrm{Cu}, 0.30$ percest $\mathrm{Pb}, 6.20$ percent $\mathrm{Zn}, 110$ grams/tonne Ag. 0.05 percenl Cd, 100 ppm Bi, and 100 ppro Co. (Bundtzen and others, 1982.)

Differentiated picrite-diorite sills that intrude Mystic Terane have magnetiterich, sulfide-bearing zones that contain up to 0.02 percent $\mathrm{Cu}, 0.06$ percent Ni. $100 \mathrm{ppm} \mathrm{Bi}$. and 0.10 percent $\mathrm{Cr}$; some network pyrhotitc-pyrite-magnetite textures noted in gabbro-diorite phases of differentiated sills. Anomalous $\mathrm{Cu}$ and Ni found in nearby streans eroding prospect area. (Bundizen and others, 1982; Reed and Elliolt, 1968b; this study.)

High grade, massive sulfide bearing diopside-ganel skan zone in carbonate xenolith within complex Teriary dike swarm; contains up to 0.04 percent $\mathrm{Cu}$, 1.30 percent $\mathrm{Pb}, 14.70$ percent Zn, 58 grams/tonne Ag. 300 ppm Co, 1,000 ppm Bi. and 200 ppm Cd. (Bundtzen and others, 1982.)

Replacemeat zone along northeast trending fault contains scheelite, chalcopyrite, and visible Au. (Bundizen and others, 1982; Rob Kell, written commun., 1984.)

Pyrrhotite-rich gossan about $10 \mathrm{ft}(3 \mathrm{~m})$ wide in fracture filling in basalticandesite flow (TKvm unit); contains 1.17 percent combined $\mathrm{Cu}-\mathrm{Pb}-\mathrm{Zn}$ with 7 grams/tonne Ag. (Bundtzen and otbers, 1982; Smith and Albanesc, 1985.)

\footnotetext{
'After Cox and Singer (1986).
} 


\section{Mineral Depasit \\ Type (\#); \\ Principal \\ Commodities \\ Description and Cited References}

10 Unnamed Low temperature $\mathrm{Pb}$

(81JC 102) Zn skarn (Deposit

$\# 18 \mathrm{c}): \mathrm{Cu}, \mathrm{Pb}, \mathrm{Zn}$,

$\mathrm{Ag}, \mathrm{Co}$

(1) Unnamed

(8) BT339)

Polymetallic vein

(Deprosic 22c); $\mathrm{Cu}$.

$\mathrm{Pb}, \mathrm{Zn} . \mathrm{Ag}, \mathrm{Au}$

12 Unnamed (81BT322-

13 Smith Lake

14 Sheep Creek or Dall

15 Rat Fork

6 Ozzna Creek Porphyry coppermolybdenum? (Deposit $\mathrm{H} 2$ la): $\mathrm{Cu}$ $\mathrm{Pb}, \mathrm{Zn} . \mathrm{Ag}$

17 Rober's PGM or Middle Fork

Disseminated (Norilsk) Ni-Cu.PGE ? (Deposit \#5b); PGE, Ni

18 Chip-Loi
Sedimentary

exhalitive $\mathrm{Pb}-\mathrm{Zn}$ ? (Deposit \#31a); $\mathrm{Pb}$ $\mathrm{Zn}, \mathrm{Ag}, \mathrm{V}$ (Deposit \#22c): $\mathrm{Cu}$. $\mathrm{Pb}, \mathrm{Zn}, \mathrm{Ag}, \mathrm{Co}, \mathrm{Bi}$

Polymetallic replacenent (Deposit \#190): Cu, Zn, Ag

Copper-iron skan (Deposit \#18b): Cu. $\mathrm{Pb}, \mathrm{Zn}, \mathrm{Ag}, \mathrm{Fe}, \mathrm{Cd}$, $\mathrm{Co}, \mathrm{Au}, \mathrm{Sn}$
Massive sulfide skam near felsic sill contains 0.50 percent $\mathrm{Cu}, 0.11$ percent $\mathrm{Pb}$, 13.0 percent $\mathrm{Zn} .26$ grams/tonne $\mathrm{Ag}$, and $300 \mathrm{ppm} \mathrm{Co}$. (Bundtzen and others. 1982.)

Silicified vein breccia in sandstone and limestone (mSs, mSI units) wilh disseminated chalcopyrite and galena along east-west fracture; contains 0.85 percent $\mathrm{Cu}, 0.98$ percent $\mathrm{Pb}, 0.58$ percent $\mathrm{Zn}, 86$ grams/tonae $\mathrm{Ag}$, and 0.85 grams/toruc Au.(Bundtzen and others. 1982.)

Random exposures of sulfurous-rich shale (SOsh unit) contain up 100.06 percent $\mathrm{Pb}, 0.17$ percent $\mathrm{Zn}, 2.7$ grams/tonne $\mathrm{Ag}$, and $1,000 \mathrm{ppm} \mathrm{V}$. (Bundtzen and others, 1982.)

N45E trending massive pyrhotite-galena-sphalerite shear zone about $3 \mathrm{f}(1 \mathrm{~m})$ thick in sandstone ( $\mathrm{mSs}$ unit) explored by $15 \mathrm{ft}(4 \mathrm{~m}$ ) adit; contains up to 1.05 percent $\mathrm{Cu}, 1.74$ percent $\mathrm{Pb}, 5.22$ percent $\mathrm{Zn}, 42$ grams/tonne Ag, 100 ppm Co, and $100 \mathrm{ppm}$ Bi. (Eundzen and others, 1982: Smich and Albanese, 1985.)

Disseminated to massive pyrite-chalcopyrite replacement zones in granite porphyry dike and SOsh shale; contains up to 5.40 percent $\mathrm{Cu}, 3.48$ percent $\mathrm{Zn}$, and 165 grams/tonne Ag. Drilled by Anaconda Minerals in 1981-82. (Rob Kcll, written commun., 1984; Smith and Albanese, 1985.)

Aerially extensive zone of sulfide-rich endo-and exoskan developed in I mile wide $(1.5 \mathrm{~km})$ granodiorite dike swarm. Disseminated to massive chalcopyrite, pymhotite, magnetite, and sphalerite formed paragenetically late garnetwollustonite diopside skan (Taceable for about $80 \mathrm{ft}(25 \mathrm{~m})$ and widths of $8 \mathrm{ft}$ $(2.4 \mathrm{~m})$. Selected zones contain up to 2.00 percent $\mathrm{Cu}$. 300 grams/tonne Ag, $2.0 \mathrm{grams} /$ tonne Au, 9.18 percent $\mathrm{Pb}, 14.10$ percent $\mathrm{Zn}, 0.12$ percent $\mathrm{Cd}$, 276 grams/tonne Ag. and $200 \mathrm{ppm}$ Sn. Two old drill pads observed on steep cirque headwall. (Bundtzen and others, 1982; Reed and Elliott, 1968b; Smith and AJbanese. 1985; this study.)

Disseminated chalcopyrite in extensive pyrite-rich halo around quartz monzonite breccia pipe at 7,205 Mtn. Contains up 100.08 percent $\mathrm{Cu}_{1} 1.50$ percem $\mathrm{Pb}$, 1.00 percent $\mathrm{Zn}, 15.0 \mathrm{grams} / \mathrm{lonne} \mathrm{Ag}$, and $2.7 \mathrm{grams} / \mathrm{tonne} \mathrm{Au}$. (Reed and Ellior. 1968b; Bundzen and others, 1982.)

Disseminated to massive pyrrhosite chalcopyrite, bravoite, and sphalerite in network-textured, gabbro-dionite sill intruding Triassic pillow basalt of Tatina River Volcanics. Bench-test studics conducted by U.S. Bureau of Mines show up 104.71 percent Ni, 0.16 percent Co. 4.68 percent $\mathrm{Cu}, 6.16$ grams/tonne Pt. $7.7 \mathrm{grams} / \mathrm{tonne} P d$, and $4.7 \mathrm{grams} / \mathrm{tonne} A u$ as recovered from a sulfide floration concentrate. (W.S. Roberts, written commun., 1984; Foley and others, 1997.)

Limassol Co-Ni-Cu? (Deposit \#8c), Cu. Ni, Co
Mossive and disseminated pyrthotite, chaicopyrite, and bravoite mineralization 1 to $2.5 \mathrm{ft}(0.3100 .75 \mathrm{~m}$ ) thick in both phyllitic sandstone (mSs unit) and mafic diabase (Tim unit); both host rocks contain up to 1.14 percent $\mathrm{Cu}, 2.2 \mathrm{I}$ percent Ni, 0.15 percent $\mathrm{Co}$, and 37.6 percent Fe. Network sulfides common in diabase. Al least 275,600 tons ( 250,000 tonnes $)$ of massive and disseminated sulfide mineralization inferted. (Gilbert and others, 1988: Неrтеid, 1968; W.S. Robers and T.K. Bundtzen, written commun., 1984.) 


\section{Mineral Deposit \\ Type (\#); \\ Principal \\ Commodities}

\section{Description and Cited References}

\begin{tabular}{|c|c|c|}
\hline 19 & $\begin{array}{l}\text { Unnamed } \\
(82 \mathrm{MK} 92-93)\end{array}$ & $\begin{array}{l}\text { Sedimentary } \\
\text { exhalitive } 9 b-2 n \text { ? } \\
\text { (Deposit \#31a), } Z n \text {, } \\
\text { Mo }\end{array}$ \\
\hline 20 & $\begin{array}{l}\text { Unnamed } \\
\text { (88BT177) }\end{array}$ & $\begin{array}{l}\text { Polymetallic vein } \\
\text { (Deposit } \$ 22 \mathrm{c} \text { ) As. } \\
\text { Au }\end{array}$ \\
\hline 2$\}$ & $\begin{array}{l}\text { Bowser Creek } \\
\text { Northeasi }\end{array}$ & $\begin{array}{l}\text { Low temperature Pb. } \\
\text { Zn Skam (Deposil } \\
\# 18 c \text { ); Pb, Zn, Ag }\end{array}$ \\
\hline 22 & $\begin{array}{l}\text { Bowser Creek } \\
\text { Central and } \\
\text { South }\end{array}$ & $\begin{array}{l}\text { Low temperature Pb- } \\
\text { Zn skam and } \\
\text { Polymetallic vein } \\
\text { (Deposit } \$ 18 \mathrm{c} \text { and } \\
22 \mathrm{c} \text { ) }\end{array}$ \\
\hline
\end{tabular}

23 Unnamed Sedimentary (83BT303) exhalieive Pb-Zn? (Deposit \#3Ia) $\mathrm{Zn}$, $\mathrm{Ag}$

24 Windy Fork Placer

25 Unnamed or Eudialyte

26 Unnamed (82BT321)

27 Unnamed (82BT316.48 6)

28 Post River Pluton

Itmenite-REE alluvial placer (Deposit \# not available) llmeniteREE, $\mathrm{Zr}$ Polymetallic vein (Deposit \#18c) U. Th, $\mathrm{Zr}, \mathrm{REE}$, gemstones

exhalitive $\mathrm{Pb}, \mathrm{Zn}$ ? (Deposit \$31b), Pb, $\mathrm{Zn}, \mathrm{Ag}$

Sedimentary exhalitive $\mathrm{Pb}, \mathrm{Zn}$ ? (Deposit $\$ 31 b), Z n$. Cu. Ag

Polymetallic vein (Deposil \#22c): $W$.
$13 \mathrm{fl}(4 \mathrm{~m})$ thick pyritc-sphalerite bearing section of Lower Silurian graptolite zone in SOsh unit averages $395 \mathrm{ppm} \mathrm{Zn}$. (Bundzen and others, 1987: this study.)

N70E quarzz vein cuts Kahilua flysch: contains 0.16 percent As and $150 \mathrm{ppb}$ Au. (Bundizen and others, 1997b; this study.)

Massive sulfide-galena-sphalerite pods up to $10 \mathrm{ft}(3 \mathrm{~m})$ wide in laminated limestone of DSt unit; contains up to 24.0 percent $\mathrm{Pb}, 22.1$ percent $\mathrm{Zn}$, and 391 grams/tonne Ag. (Red and Elliott, 1968a; Bunduen and others, 1987.)

Bowser Crcek Central contains several sphalerite-chalcopyrite-quartz veins hosted in $60 \mathrm{Ma}$ quarz porphyry phase of Bowser Creek pluton; veins can be raced for about $450 \mathrm{ft}(137 \mathrm{~m})$; Bowser Creek South is massive galena-sphalerite (blackjack)-pyrrhotite-johannsenite pods in marble front adjacent to monzonite breccia pluton. Best assays from both deposits are 1.09 percent $\mathrm{Cu}, 23.7$ percenl $\mathrm{Pb}, 12.3$ percent $\mathrm{Zn}_{\mathrm{n}} 169 \mathrm{Ppm} \mathrm{Co}$, and 2,510 grams/tonne Ag. Modest production of high grade silver ore shipped by aircraft in 1969-73. (Reed and Elliolt, 1968a; Bundzen and others. 1987.)

Three 4 in $(10 \mathrm{~cm})$ thick pyrite bands in SOsh unit contain dissemirated sphalerite; one sample contained $700 \mathrm{ppm} \mathrm{Zn,} 1.2$ grams/tonne Ag, and 31 ppm Mo. (Bunduen and others, 1987.)

Extensive alluvium sampled at the intersection of tributary stream draining Windy Fork pluton and Windy Fork averages several percent ilmenite and monazite, and up to 2.0 percent zircon. Cenium concentrations noted in trace element analyses. (Jim Barker, written commun., 1996); Gilbert and others, 1988.)

Hematitc-quarz feldspar veins in joints of Windy Fork Granite contain up to

$490 \mathrm{ppm} U$, and 404 ppm Th in two localities; eudialyte (a zirconium-REE silicate) was observed in taius associated with a homblende pegmatite phase of the pluton. (Reed and Miller, 1980; Gilbert and others. 1988.)

Chip samples of sulfurous shales of SOsh unit contain up to 0.87 percent $\mathrm{Zn}$. 0.02 percent $\mathrm{Pb}$, and 4.5 grams/tonne Ag. (Bundtzen and others, 1987.) $\mathrm{Sn}, \mathrm{Cu}, \mathrm{Ph}, \mathrm{Ag}$
Random chip samples of sulfurous SOsh shales in Lower Silurian graptolite zone contain up to 1.37 percent $\mathrm{Zn}, 0.12$ percent $\mathrm{Cu}$, and 13.6 grams/tonne $\mathrm{Ag}$. (Bundzen and ohers. 1987.)

Three ft $(\mathrm{l} \mathrm{m})$ wide chalcopyrite-scheelite-quartz vein in skam and several small veíns in border phase of $62 \mathrm{Ma}$ Post River pluton contain up to 1.15 percent $\mathrm{Cu}$. 0.18 percent $\mathrm{Pb}, 0.03$ percent W, 0.09 percent Sn. and 98 grams/tonne Ag. (Bundizer and others. 1987.) 


\section{Mineral Depasit \\ Type (H); \\ Name of Deposit Principal \\ Commodities \\ Description and Cited References}

\begin{tabular}{|c|c|c|c|}
\hline 29 & $\begin{array}{l}\text { Post Lake } \\
\text { Prospect }\end{array}$ & $\begin{array}{l}\text { Polymetallic } \\
\text { replacement (Deposit } \\
\# 19 \text { a): } \mathrm{Cu}, \mathrm{Zn} . \mathrm{As} \text {, } \\
\mathrm{Co} . \mathrm{Ni}\end{array}$ & $\begin{array}{l}\text { Fracture controlled massive pytrhotite deposits cut altered shale (SOsh unit) in } \\
\text { bedrock canyon near contact with quart moazonite stock. Sulfide zones range } \\
\text { from } 1.5 \text { to } 6 \text { ft }(0.5 \text { to } 2.0 \mathrm{~m} \text { ) wide and } 65 \text { to } 260 \mathrm{ft}(20 \text { to } 80 \mathrm{~m} \text { ) long and } \\
\text { contain up to } 570 \mathrm{ppm} \mathrm{Cu}, 156 \mathrm{ppm} \mathrm{Co} 378 \mathrm{ppm} \mathrm{As}, 302 \mathrm{ppm} \mathrm{Zn,} \mathrm{and} 637 \mathrm{ppm} \\
\text { Ni. (Bundtzen and others, } 1987 .)\end{array}$ \\
\hline 30 & $\begin{array}{l}\text { Unnamed } \\
\text { (88HAS.6) }\end{array}$ & $\begin{array}{l}\text { Au placer (Deposit } \\
\# 39 \mathrm{a} \text { ), Au }\end{array}$ & $\begin{array}{l}\text { Pan concentrate from second order stream cutting Eocene Terra Cotta volcanic } \\
\text { field contains several grains of gold. (This study.) }\end{array}$ \\
\hline 31 & $\begin{array}{l}\text { Unnamed } \\
(88 \mathrm{BT} 169)\end{array}$ & $\begin{array}{l}\text { Creede epithermal } \\
\text { vein? (Deposit } \\
\text { W25b), As. Au. (Co), } \\
\text { W. Sb }\end{array}$ & $\begin{array}{l}\text { Sulfide gossan zone in quartz-eyed rhyodacite ruff yields } 240 \mathrm{ppb} \text { Au. } \\
0.22 \text { percent As, } 880 \mathrm{ppm} \mathrm{W.} 110 \mathrm{ppm} \mathrm{Co,} \mathrm{and} 200 \mathrm{ppm} \text { Sb. (This study.) }\end{array}$ \\
\hline 32 & $\begin{array}{l}\text { Unnamed } \\
\text { (88HA8,10,1 } \\
1.12)\end{array}$ & $\begin{array}{l}\text { Alluvial placer } \mathrm{Sr} \\
\text { (Deposit } \$ 39 \mathrm{e}) ; \mathrm{Su} \\
\mathrm{W}\end{array}$ & $\begin{array}{l}\text { Pan concentrates from several first and second order streams cutting Kahiltna } \\
\text { terrane and } 59 \mathrm{Ma} \text { South Fork Granite contain } 0.022 \text { to } 1.00 \text { percent } S a .0 .023 \text { to } \\
0.14 \text { percent } W \text {, and up to } 11 \mathrm{ppm} \text { Ta. (This sndy.) }\end{array}$ \\
\hline 33 & $\begin{array}{l}\text { Unnamed } \\
(88 \mathrm{BT} 150, \\
15 \mathrm{~L})\end{array}$ & $\begin{array}{l}\text { Creede epichermal } \\
\text { vein ? (Deposit } \\
\text { \#2Sb): As, Au, Sb, } \\
\text { Zn }\end{array}$ & $\begin{array}{l}\text { Intense zone of adularia-kaolinite-ferricrete bydrothermal alteration in dacite- } \\
\text { andesite flows of Eocene Terra Cotta volcanic field. Grab samples of fault breccia } \\
\text { and gossan zone over } 350 \text { feet ( } 107 \mathrm{~m} \text { ) of strike and } 150 \mathrm{ft}(46 \mathrm{~m} \text { ) in width } \\
\text { contains } 0.42 \text { percent As. } 360 \mathrm{ppb} \text { Au, } 0.21 \text { percent } \mathrm{Zn} \text {, and } 150 \mathrm{ppm} \text { Sb. (This } \\
\text { study.) }\end{array}$ \\
\hline 34 & $\begin{array}{l}\text { Unuamed } \\
\text { (88BTL63- } \\
165)\end{array}$ & $\begin{array}{l}\text { Polymetallic vein } \\
\text { (Deposit } \$ 22 c) ; A u \text {. } \\
\text { W. As, Ag, Cu }\end{array}$ & $\begin{array}{l}\text { Grab samples of galena-chalcopyrite-pyrite-quartz vein stockwork in Hartman } \\
\text { pluton from corc to eastem edge contiuns up to } 180 \mathrm{ppb} \mathrm{Au}, 710 \mathrm{ppm} \mathrm{W} \text {, } \\
830 \mathrm{ppm} \text { As, and } 27 \text { grams/tonne Ag. (This study.) }\end{array}$ \\
\hline 35 & $\begin{array}{l}\text { Unnamed } \\
\text { (88DNS107) }\end{array}$ & $\begin{array}{l}\text { Creede epithermal } \\
\text { vein ? vein (Deposit } \\
\# 25 b \text { ); } A u, A s, W, S b\end{array}$ & $\begin{array}{l}\text { Pyrite rich-quartz veins, which locally carry galena, cut dacite intrusion and } \\
\text { dacite lapilli turf near contacs with Kahilua flysch. Talus grab samples carry up } \\
\text { to } 0.40 \text { percent } A s, 2,100 \text { ppb Au, } 550 \text { ppm W, and } 110 \text { ppm Sb. (This sndy.) }\end{array}$ \\
\hline
\end{tabular}




\section{REFERENCES CITED}

Armstrong, A.K., Harris, A.G., Reed, B.L., and Carter. Claire, 1977, Paleozoic sedimentary rocks in the nonthwest part of the Talkeetna quadrangle, Alaska Range, in Blean, K.M., ed., U.S. Geological Survey Accomplishments During 1976: U.S. Geological Survey Circular 751-B, p. B61-B62.

Blodgett, R.B., and Gilber, W.G., 1992, Upper Devonian shallow marine siliciclastic strata and associated fauna and Rora, Lime Hills D-4 quadrangle. Alaska, in Bradley, D.C., and Dusel-Bacon, Cynchia, eds., Geologic studies in Alaska by the U.S. Geological Survey, 1991: U.S. Geological Survey Bulletin 2041, p. 106-115.

Brooks, A.H., 191 I, The Mount McKinley region. Alaska: U.S. Geological Survey Professional Paper 70, p. 69-77.

Bundtzen, T.K., and Gilben, W.G., 1983, Outline of the geology and mineral resources of the upper Kuskokwim region, Alaska, in Reed, K.M., and Mull C.G., eds., Western Alaska geology and resource potential: Journal of the Alaska Geologicai Society, v. 3, p. $101-117$.

Bundtzen, T.K., Gilbert, W.G., Smith, T.E., and Lockwood, M.S., 1997a. Geologic map of the McGrath B-l Quadrangle, Alaska: Alaska Division of Geological \& Geophysical Surveys, in progress, scale 1:40,000.

Bundzen. T.K., Harris, E.E.. Solie, D.N., and Kline, J.T. 1997b, Geologic map of the McGrath A-1 Quadrangle. Alaska: Alaska Division of Geological \& Geophysical Surveys, in progress, scale 1:63.360.

Bunduen, T.K., Kline, J.T., and Clough, J.G., 1982, Preliminary geology of the McGrath B-2 Quadrangle, Alaska: Alaska Division of Geological \& Geophysical Surveys Open-File Report 149, 22 p., scale $1: 40,000$.

Bundtzen, T.K., Kline, J.T., Smith, T.E., and Albanese, M.D., 1987, Geologic map of the McGrath A-2 Quadrangle, Alaska: Alaska Division of Geological \& Geophysical Surveys Professional Repor 91,21 p. scale $1: 63,360$.

Bundtzen, T.K., Laird, G.M., Blodgent, R.B., Clautice, K.H., and Harris, E.E., 1994. Geologic map of the Gagaryah River area, Lime Hills C-5 and C-6 Quadrangles, southwestern Alaska: Alaska Division of Geological \& Geophysical Surveys Public-Data File $94-40,16$ p. scale $1: 63,360$.

Bundtzen, T.K., and Miller, M.L., 1997. Precious metals associated with Late Cretaceous-early Teriary igneous rocks of southwestem Alaska: Economic Geology Monograph \#9, p. 349-393.
Churkin, Michael Jr., and Carter, Claire, 1996. Suatigraphy, structure, and graptolites of an Ordovician and Silurian sequence in the Terra Cotta Mountains, Alaska Range, Alaska; U.S. Geological Survey Professional Paper 1555, 84 pages, 3 plates, various scales.

Churkin, Michael Jr., Reed, B.L., Carter, Claire, and Winkler, G.R., 1977, Lower Paleozoic graptolise section in the Terra Cotta Mountains. Alaska in Blean, K.M., ed., The United Stares Geological Survey in Alaska-Accomplishments during 1976: U.S. Geological Survey Circular 751-B, p. B37-B38.

Cox, D.P. and Singer, D.A., eds., 1986 Mineral Deposit Models: U.S. Geological Survey Bulletin 1693. $379 \mathrm{p}$.

Decker, John, and Gilbert, W.G., 1978, The Mount Galen volcanics-a new middle Tertiary volcanic formation in the central Alaska Range: Alaska Division of Geological \& Geophysical Surveys Geologic Report $59.11 \mathrm{p}$.

Decker, John, Bergman, S.C., Blodget, R.B., Box, S.E., Bundtzen, T.K., Clough, J.G., Coonrad, W.L., Gilbert, W.G., Miller, M.L.. Murphy, J.M., Robinson, M.S., and Wallace, W.K., 1994, Geology of southwestern Alaska, in Plafker, George, and Berg. H.C., eds., The Geology of Alaska: Boulder, Colorado, Geological Society of America, The Geology of North America, v. G1, p. 285-310.

Dickey, D.B., 1984, Cenozoic nonmarine sedimentary rocks of the Farewell fault zone. McGrath Quadrangle, Alaska: Sedimentary Geology, v. 38. p. $443-463$.

Dickinson, W.R., and Suczek, C.A., 1979, Plate tectonics and sandstone compositions: American Association of Petroleum Geologists Bulletin, v. 63, no. 12, p. 2164-2182.

Eakins, G.R., Gilbert, W.G., and Bundtzen, T.K., 1978, Preliminary bedrock geology of the west-central Lake Clark Quadrangle, Alaska: Alaska Division of Geological \& Geophysical Surveys Open File report 118, 15 o., 2 sheers, scale $1: 125,000$.

Fernaid, A.T., 1960, Geomorphology of the upper Kuskokwim region, Alaska: U.S. Geological Survey Bulletin 1071-G, p. 191-279.

Foley, J.Y., Light. T.D. Nelson, S.W., and Harris, R.A., 1997, Mineral occurrences associated with maficultramafic and related alkalic complexes in Alaska: Economic Geology Monograph \#9, p. 216-270.

Folk, R.L., 1968, Petrology of sedimentary rocks: Austin, Texas. Hemphills Book Store, 170 p.

Forbes, R.B., Smith, T.E., and Turner, D.L., 1974, Comparative petrology and structure of the McKlaren, Ruby Range. and Coast Range belts: Implications for offser along the Denali fault system: Geological 
Society of America Abs. with Programs (Cordilleran Section), v. 6, no. 3., p.177

Gabrielse, Hugh, 1963, McDame map area, Cassiar district, British Columbia: Geological Survey of Canada Memoir 319. 138 p.

Gilbert, W.G., 1981, Preliminary geologic map of the Cheeneetnuk River area, Alaska: Alaska Division of Geological \& Geophysical Surveys Open File Report 153, 19 p., 2 sheets, scale 1:63,360.

Gilbert, W.G., and Bundizen, T.K., 1979, Mid-Paleozoic fectonics, volcanism, and mineralization in north-central Alaska Range: in Sisson, Alex, ed.. The Relationship of plate tectonics to Alaskan geology and resources: Anchorage, Alaska Geological Society, v. 2, p. F1-F22, 2 sheets, scale 1:250,000.

Gilber, W.G., and Bundizen, T.K.. 1983, Two stage amalgamation of west-central Alaska [abs.]: Geological Society of America Cordilleran and Rocky Mountain Sections, Abstracts with Programs, v. 15, no. 5, p. 428 .

Gilbert, W.G., and Bundzzen, T.K., 1984, Stratigraphic relationship between Dillinger and Mystic teranes, western Alaska Range [abs.]: Geological Society of America, Cordilleran Section. Abstracts with Programs, v. 16, no. 5. p. 286.

Gilbert. W.G., Ferrell, V.M., and Tumer, D.L., 1976, The Teklanika Formation-a new Paleocene volcanic formation in the Central Alaska Range: Alaska Division of Geological \& Geophysical Surveys Geologic Report 47, 16 p., scale 1:63,360.

Gilber, W.G., Nye, C.J., and Sherwood, K.W., 1984, Stratigraphy, petrology, and geochemistry of Upper Triassic rocks from the Pingston and McKinley terranes, central Alaska Range: Alaska Division of Geological \& Geophysical Surveys Report of Investigations $84-30,14 \mathrm{p}$.

Gilbert, W.G., Solie, D.N., and Kline, J.T., 1988, Geologic map of the McGrath A-3 Quadrangle, Alaska: Alaska Division of Geological \& Geophysical Surveys Professional Report 92, 2 sheets, scale 1:63,360.

Gilber, W.G., Solie, D.N., Kline J.T., and Dickey, D.B., 1990. Geologic map of the McGrath B-3 Quadrangle, Alaska: Alaska Division of Geological \& Geophysical Surveys Professional Repor 102, 2 sheets, scale $1: 63.360$.

Gordey, S.P., and Anderson, R.G., 1993, Evolution of the northern Cordilleran Miogeocline, Nahanni map area. Yukon and Northwest Territories, Canada: Geological Survey of Canada Memoir 428, 214 p., 4 sheets. scale $1: 250,000$.

Gunter, M.E., Johnson, N.E., Knowles. C.R., and Solie, D.N., 1993. Optical, $x$-ray, and chemical analysis of four eudialytes from Alaska: Mineralogical Magazine, v. 57, p. 74l-744.
Henning, M.W., Meyer, John. Kombrath, Richard and Krouskop. D.L., 1984, Geologic and gravity evaluation of oil and gas potential of the Minchumina basin. Alaska: In, Geological Sociery of America, Cordilleran Section, Abstracts with Programs, v. 16. no. 5, Anchorage, Alaska, p.289.

Herreid, Gordon, 1968, Geological and geochemical investigations southwesı of Farewell, Alaska: Alaska Division of Geological \& Geophysical Surveys Geologic Report 26, $24 \mathrm{p}$.

Jones, D.L., and Silberling, N.J., 1979, Mesozoic stratigraphy: The key to tectonic analysis of southern and central Alaska: U.S. Geological Survey Open-File Report 79-1200, $41 \mathrm{p}$.

Jones, D.L., Silberling, N.J., Gilbert, W.G., and Coney, P.J., 1983, Tectonostratigraphic terrane map and interpretive bedrock geologic map of the Mount McKinley region, Alaska: U.S. Geological Survey Open-File report 83-11, scale 1:250,000.

Jones, D.L., Silberling, N.J., and Coney, P.J., 1986, Collision tectonics in the Cordilleran of western North America: Examples from Alaska, in Coward, M.P., and Ries, A.C., eds., Collision tectonics; Geological Society of London Special Publication 19, p. 367-387.

Kline, J.T., and Bundtzen, T.K., 1986. Two glacial records from west-central Alaska, in Hamilton. T.D. Reed. X.M., and Thorson, R.M., eds., Glaciation in Alaska: the geologic record: Anchorage, Geological Society of Alaska, p.123-150.

Kline, J.T., Gilbern, W.G., and Bundtzen, T.K., 1986, Geologic map of the McGrath C-1 Quadrangle, Alaska: Alaska Division of Geological \& Geophysical Surveys Report of Investigations 86-25, scale 1:63,360.

Kline, J.T, and Pinney, D.S., 1997. Derivative map of geologic materials and hazards in the eastern half, McGrath Quadrangie, Alaska: Alaska Division of Geological \& Geophysical Surveys Report of Investigations $97-14 \mathrm{~b}$, one sheet, scale 1:125,000.

Meyer, J.F., and Krouskop, D.L., 1986, Preliminary gravity data for the Minchumina basin, south-ceniral Alaska: Alaska Division of Geological \& Geophysical Surveys Report of Investigations 86-1, 14 p., 2 sheets, 1:1,000,000 scale.

Moll-Stalcup, EJ., 1994, Latest Cretaceous and Cenozoic magmatism in Mainland Alaska, in Plafker, George, and Berg, H.C., eds., The Geology of Alaska: Boulder, Colorado, Geological Society of America, Geology of North America, v. G-1, p. 589-619.

Mutti, Emilliano, and Ricci Lucchi, Franco, 1972. Turbidites of the northern Apennines, in Introduction to Facies Analysis: American Geological Institute Reprint Series no. 3, International Geology Review: v. 20 , no. 20 , p. $125-166$.

Nokleberg, W.J., Plafker, George, and Wilson F.H., 1994. 
Geology of south-central Alaska, in Plafker, George, and Berg, H.C., eds., The Geology of Alaska: Boulder, Colorado, Geological Society of America, Geology of North America, v. G1, p. 311-366.

Parton, W.W. Jr., Box. S.E., Moll-Stalcup. E.J., and Miller, M.L., 1994, Geology of west-central Alaska. in Plafker, George, and Berg, H.C., eds., The Geology of Alaska: Boulder, Colorado, Geological Society of America, Geology of North America, v. GI, p. 241-271.

Pearce, J.A., and Cann, T.R., 1973, Tectonic setting of basic volcanic rocks determined using trace element analyses: Earth and Planctary Science Letzers, v. 19. p. $290-300$.

Plafker, George, and Berg, H.C., 1994, Overview of the Geology and tectonic evolution of Alaska, in Plafker. George, and Berg, H.C., eds., The Geology of Alaska: Boulder, Colorado, Geological Society of America, Geology of North America, v. GI, p. 989-1022.

Reed, B.L., and Eberlein, G.D. 1972. Massive sulfide deposits near Shellabarger Pass, southern Alaska Range, Alaska: U.S. Geological Survey Bulletin 1342,45 p., I sheec scale 1:300.

Reed, B.L., and Elliott, R.L., 1968a, Lead, zinc and silver deposits at Bowser Creek. McGrath A-2 quadrangle, Alaska: U.S. Geological Survey Circular 559, $17 \mathrm{p}$.

Reed, B.L.، and Ellioth, R.L., 1968b, Geochemical anomalies and metalliferous skams between Windy Fork and Post River, southern Alaska: U.S. Geological Survey Circular 596, 22 p.

Reed, B.L., and Lanphere, M.A., 1972, Generalized geologic map of the Alaska-Aleutian Range batholith showing potassium argon ages of plutonic rocks: U.S. Geological Survey Miscellaneous Field Investigations Map MF-372, 2 sheets, scale 1: 1,000,000.

Reed, B.L., and Larphere, M.A., 1974, Offset plutons and history of movement along the McKinley segment of the Denali fault system. Alaska: Geological Sociely of America Bulletin, v. 85, no. 12, p. 1883-1892.

Reed. B.L., and Lanphere, M.A., 1980, Uranium and thorium contents of some Tertiary granitic rocks in the southern Alaska Range: U.S. Geological Survey Open-File Report 80-1052, $16 \mathrm{p}$.

Reed, B.L., and Nelson, S.W., 1980, Geologic map of the Talkeetna quadrangle. Alaska: U.S. Geological Survey Miscellaneous lnvestigations Map L-1174, scale 1:250,000.

Sloan, E.G., Shearer, G.B., Eason, J.E.. and Alnquist. C.L., 1979, Reconnaissance survey for coal near
Farewell, Alaska: U.S. Geological Survey Open-File Report 79-410. 18 p., 4 plates, scale 1:2,000.

Smith. T.E., and Albanese, M.D., 1985. Preliminary prospect examinations in the McGrath A-7, A-3, and B-2 quadrangles, Alaska: Alaska Division of Ceological \& Geophysical Surveys Public-Data File Repor $85-54,19$ pages.

Solie, D.N., 1983, The Middie Fork plutonic complex, McGrath A-3 Quadrangle, southwest Alaska: Alaska Division of Geological \& Geophysical Surveys Report of Investigations 83-16, $22 \mathrm{p}$.

Solie, D.N, 1988. The Middle Fork plutonic complex: a plutonic association of coeval peralkaline and metaluminous magmas in west central Alaska Range: unpublished dissertation, Virginia Polytechric Institute and State University, Blacksburg, Virginia, 242 p., 2 plates.

Solie, D.N., Bundizen, T.K., and Gilbert, W.G., 1991, $\mathrm{K}$-Ar ages of igneous rocks in the McGrath Quadrangle, Alaska: Alaska Division of Geological \& Geophysical Surveys Public-Data File 91-23, 8 p., scale 1:250,000.

Solie, D.N., and Dickey, D.B., 1982, Coal occurrences and analyses. Farewell-White Mountain area, Alaska: Alaska Division of Geological \& Geophysical Surveys Open File Report 160, 17p.

Stevens, C.C., 1971, A provenance study of the Tertiary sandstones in the Healy Creek and Lignite Creek coal basins, Alaska: Fairbanks, unpublished dissertation. University of Alaska M.S. Thesis, $122 \mathrm{p}$.

Szumigala. D.J., 1987, Geology of the lead-zinc skarn deposits of the Tin Creek area, McGrath B-2 Quadrangle, Alaska: Alaska Division of Geological \& Geophysical Surveys Report of Investigations 87-5, 21 p.

Thorson, R.M.. 1986, Late Cenozoic glaciation of the norkern Nenana valley, in Hamilon, T.D., Reed. K.M., and Thorson, R.M., eds., Glaciation in Alaska: the geologic record: Anchorage, Geological Society of Alaska, p. 99-121.

Wahrhafiig. Clyde, 1965, Physiographic divisions of Alaska: U.S. Geological Survey Professiona! Paper $482,52 \mathrm{p}$.

Wahrhaftig. Clyde, Bartsch-Winkler, Susan, and Stricker, G.D., 1994, Coal in Alaska, in Plafker, George, and Berg, H.C.. eds.. The Geology of Alaska: Boulder, Colorado, Geological Society of America, Geology of North America, v. G1, p. 937-978.

Wahrhaftig, Clyde, Wolfe, J.A., Leopold, E.B., and Lanphere, M.A., 1969, The coal-bearing group in the Nenana coal field, Alaska: U.S. Geological Survey Bulletin 1274-D, p. Di-D30. 

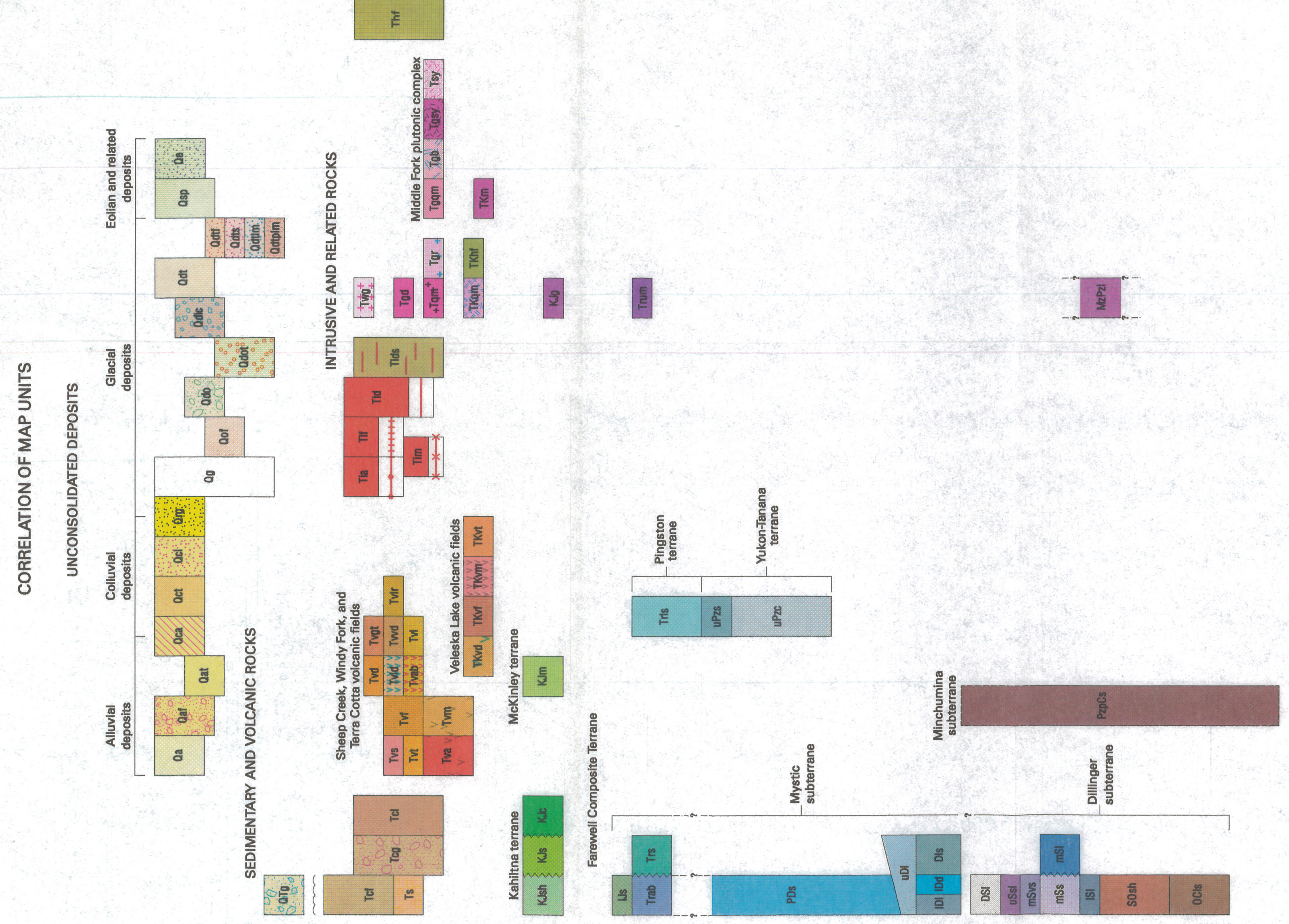


\title{
DESCRIPTION OF MAP UNITS
}

\section{UNCONSOLIDATED DEPOSITS}

\author{
ALLUVIAL DEPOSITS
}

Qa

STREAM ALLUVIUM, UNDIFFERENTLATED-Fluvial silt, sand, and gravel deposited by streams in Holocene floodplains, fans, and meandering to distributary stream channel deposits. Grain size, sorting. and degree of stratification vary according to stream size, bedrock source. gradient, and flow regime. Clasts of local and distal derivation indicate a mixture of local bedrock and glacial provenance. Unit ranges from a few meters thick in small gulches $1035 \mathrm{ft}(11 \mathrm{~m})$ thick in alluvial fans, plains, and piedmont slopes. Unit $\mathrm{Qa}$ is Holocene in age throughout study area. Very nonresistant and unconsolidated; generally thawed, except where covered by climax vegetation.

Qaf ALLUVIAL-FAN DEPOSITS-Poorly to moderately well sorted, gray to tan (oxidized). fluvial silt, sand, and gravel deposited where first- and second-order tributaries join third-and fourth-order streams. Unit appears as deltaic fans in the Alaska Range, and as extensive piedmont aprons that flank foothills north of the DenaliFarewell fault zone, northwest of St. John's Hill. Smaller Qaf deposits that originate in steep streams and gullies tend to be poorly sored, whereas larger Qaf accumulations in third-and fourth-order streams are better sorted and more mature. Qaf ranges from late Wisconsin to Holocene. Unit is moderately resistant due to calcareous cementation of Alaska Range deposiss. Generally thawed except in zones of northerly aspect. Unit ranges from 6.5 to $50 \mathrm{ft}$ ( 2 to $15 \mathrm{~m}$ ) thick, and can be considered an excellent source of construction materials where not covered by eolian silt and sand.

Qat TERRACE ALLUVIUM-Moderately to well soned, well stratified, gray to tan (oxidized), fluvial silt, sand, and gravel of varying ages deposited on former floodplains that now lie above or beyond the normal depositional regime of Holocene streams. Unit is generally preserved in larger third- and fourth-order stream valleys, covered by pioneer to climax vegetation, dissected by Holocene streams, and blankesed with eolian silt and sand. Unit ranges in age from Wisconsin to early Holocene, and ranges from 10 to $35 \mathrm{ft}(3$ to $11 \mathrm{~m})$ thick in exposed stream cuts. Cementation and permafrost may both be present. Older Qat deposits may contain highly weathered ciasts in a sitty matrix, and thus may not be suitable as construction materials.

\section{COLLUVIAL DEPOSITS}

Qca COLLUVIAL-ALLUVIAL DEPOSITS-Mixed or alternating, poorly to moderately soned, silt, sand, gravel and diamicton of colluvial and alluvial origins. In srudy area unit appears in the Alaska Range and northeastem foothills within steep gullies, and at the intersection of first-order tributary and second- or higher-order streams. Colluvial-alluvial fass are most active when intense freeze-thaw cycles occur and large quantities of meltwater are present. Engineering applications vary widely due to large grain size and soring properties. Generally frozen in steep mountain sentings. Ranges from several to $100 \mathrm{ft}(30 \mathrm{~m})$ thick.

Qce TALUS-Angular, unsorted debris derived from frost riving of bedrock followed by rapid gravity transport on steep slopes, cirque headwalls, steeg gullies, and avalanche chutes. Unit forms most commonly as cones or aprons that lie at, or near, the angle of repose along valley walis; distal, upvalley ends may grade into rock glacier deposits. Usually frozen and widely varies from 10 to 30 ft ( 3 to $9 \mathrm{~m}$ ) thick.

QCI LANDSLIDE DEPOSITS-Chaotically deformed colluvium derived from relatively sudden mass movemenı of bedrock or surficial deposits along a plane of failure. Surface of deposit is characteristically hummocky and commonly lies below a well-defined failure scarp. Recent landslide deposits display surface disturbances such as randomly tilted trees. disrupted vegetation, and water-filled depressions. All Qel deposits are frozen and Holocene age. 


\section{EOLLAN AND RELATED DEPOSITS}

Qsp SILT AND PEAT-Poorly stratified, black to brown, organic rich, alluvial, eluvial, lacustrine, and bog silt and peat. Unit Qsp formed in extensive wetlands overlying outwash fan deposits ( $Q \circ f)$ on the piedmont plain in north-central portion of study area. Unit generally consists of mulsiple stacked palsas each up to $10 \mathrm{ft}(3 \mathrm{~m})$ thick. Usually frozen except near stream cuts. Ranges in age from Late Wisconsin to Holocene: sorne silt and peat are forming today. Unit might be suitable for horticulsural or energy applications.

Qe EOLIAN DEPOSITS-Well-soned sand and silt transported and deposited by wind. Appears near cliff heads and bluffs where unir is up to $60 \mathrm{fr}(18 \mathrm{~m})$ thick. A widespread tephra layer of Holocene age (about $1,800 \mathrm{yr}$ old: Kline and Bundezen, 1986) occurs in loess banks in several localities along South Fork and Big Salmon Fork. Sand deposits are usually dry and thawed, but do nor make good construction materials. Silt is cornmonly frozen and ice-rich when buried under climax vegetation.

\section{GLACIAL AND RELATED DEPOSITS}

Qg ACTIVE GLACIERS-Occupy cirques having base levels above 4,800 to $6,100 \mathrm{ft}(1,500$ to $1,900 \mathrm{~m})$ elevation; most glaciers exhibit a strong northerly aspect. Glaciers range in size from 0.4 to 5 square miles ( $1 \mathrm{~km}^{2}$ to about $\left.12 \mathrm{~km}^{2}\right)$; the largest are nested in Middle Fork and Windy Fork intrusive massifs. Termini are generally 4,300 to $5,000 \mathrm{ft}(1,300$ to $1,500 \mathrm{~m})$ in elevation. Most glaciers in study area appear to be in retreat.

Qrg ROCK GLACIERS AND ROCK-GLACIER DEPOSITS-Unsorted. angular, frost-shattered cobbles and boulders, commonly contaíning considerable interstitial ice (up to 55 percent in active rock glaciers). Unit generally originates at 3,500 to $5,000 \mathrm{ft}(1,100101,500 \mathrm{~m})$ elevation in north-facing cirques or on steepened slopes of blocky-weathered, resistant bedrock; may transcend into true glaciers or talus. We recognize three morphological types in the eastern McGrath Quadrangle: (1) lobate forms 165 to $660 \mathrm{ft}$ ( 50 to $200 \mathrm{~m}$ ) across that lie at the base of valley walls and are moving toward the valley axis; (2) tongue-shaped forms that head in cirques and have their longest dimension parallel to flow direction; and (3) transitional forms that are elongated down-valley in direction of flow (heads may be true glaciers). Unit appears throughout Alaska Range portion of map area, but is particularly well developed in areas underlain by Mesozoic Kabiltna flysch terrane, and intrusive rocks of all ages. Fronts of active rock glaciers are very steep and unstable. Generally not suitable for construction materials due to large clast size. Usually frozen. Resistant due to interstitial ice component.

Qof OUTWASH-FAN DEPOSTSS-Glaciofluvial sand and silt derived from streams originating near ancestra! glacial margins. Anastomosing channel scars appear on many outwash-fan surfaces; the most prominent have become reactivated as modern alluvial deposits ( $Q$ a). Qof forms extensive piedmont aprons that flank the mountain front along the Farewell-Denali fault and extend norhward for several tens of kilometers. Unit ranges in thickness from 13 to $26 \mathrm{ft}$ ( 4 to $8 \mathrm{~m}$ ), is covered by extensive surface vegetation, and is frequently frozen. Qof ranges in age from middle Pleistocene to early Wisconsin: ages assigned to deposits depend on correlation with specific glaciation.

Qdo OUTWASH-Stratified drift consisting of coarse subrounded gravel that contains sand and silt lenses deposired by sideglacial and proglacial meltwater streams. Anastomosing channel scars appear on many outwash surfaces that have otherwise little or no surface relief. Deposits tend to be progressively finer grained downstream from terminal glacial sources, but coarser grained than sediments in outwash fan deposits (Qof). May be excellent sources of sand and gravel, but suitability depends on testing specific sités for engineering properties. Generally Wisconsin in age throughout study area and considered younger than Qof. Thickness is variable ( 10 to $16 \mathrm{~d} ; 3$ to $5 \mathrm{~m}$ ); unit is usually frozen, but contains less than 10 percent ice.

Qdot OUTWASH TERRACE-Remnant of former outwash fan or plain deposit (Qof) that has been dissected by Wisconsin to Holocene streams (Qa). Terrace believed to be Early to middle Pleistocene in age, and may not be suitable for construction (sand and gravel) due to in situ weathering of clasts. Thickness unknown. 
Qdic ICE-CONTACT DEPOSITS-Stratified gravel, sand, and flowtill deposited on, against, or under stagnan! masses of glacial ice by meltwater streams. Individual layers within the deposit are extremely variable in lateral extent, degree of soring, and thickness. Extreme surface relief is common, and kame and kettle terraces are conspicuous geomorphological features of unit. Both Wisconsin and early Holocene Qdic deposits mapped in siudy area. Thicknesses not measured; generally thawed and locally suitable for construction materials.

Qdt TLL, UNDEFFERENTIATED-Unsoned to poorly sorted clay, silt, sand, and gravel deposited by glacial ice. Cobble and boulder clasts are commonly polyhedrally faceted, striated, and subangular to rounded. In siudy area unit includes till deposited during Farewell II glaciation of late Wisconsin age, but mainly consists of till of several unnamed Holocene glaciations in the Alaska Range (Kline and Bundtzen, 1986). Till comprising moraines near mountain front is commonly frozen, and covered by up to $34 \mathrm{ft}(10 \mathrm{~m})$ of peat. Thickness can achieve $164 \mathrm{ft}(50 \mathrm{~m})$ locally, but averages $34 \mathrm{fl}(10 \mathrm{~m})$ throughout map area.

Qdtf TILL OF FAREWELL GLACIATIONS-Unsorted to poorly soned clay, silt, gravel, and boulders deposited by glacial ice as ground, terminal. and lateral moraines. Unit Qdif mainly comprises till of Farewell I and Farewell II glaciations (Femald, 1960) which are regarded as early and late Wisconsin in age, respectively (Kline and Bundizen, 1986). Farewell I till is marked by moraines of at least two major advances or stades, and is covered by poorly drained, permafrost-rich soils; a few ponds and lakes that cover Farewell I vill are of thermokarst rather than glacial origin. Farewell II till contains moraines of at least four major stades or advances and is covered by crevasse-fill kame terraces, locally well developed kame deltas, up to 35 kettles per square mile (20 kettles per $\mathrm{km}^{2}$ ), and fresh glacial erratics of mainly granitic origin. Large glacial lakes including Farewell Lake formed in moraine in the first Farewell II advance. Unit exhibits differing enginee ing properties depending on drainage and age. Generally poor source of sand and gravel because of poor sorting and high clay content; however, some thin outwash gravels in or on top of till may be useable. Bearing strength depends on permafrost content, slope aspect, and silt and peat content.

Qdis TILL OF SELATNA GLACIATION-Unsorted to poorly sorted clay, silt and gravel deposited by glacial ice in ground moraines. Unit is characterized by highly modified moraine along the South Fork and Windy Fork of the Kuskokwim River (Fernald, 1960). Moraines form an arcuate pattem of discontinuous segments broken by trains of outwash (Qdo). Loess cover on unit Qdts thickens distally from the mountain front and is more than $34 \mathrm{ft}(10 \mathrm{~m})$ thick on Lone Mountain immediaiely west of the westem map boundary. Kettle topography is still present but most lakes ore partially to totally drained; about half of the circular kettle-like depressions are actually of thermokarst origin. Generally considered a poor source of sand and gravel; no outwash identified in unit. High peat content and permafrost make for poor bearing strength.

QdtIm TILL OF LONE MOUNTAIN GLACLATION-Isolated patches of unsorted to poorly sorted silt, gravel, and highly eroded ersatics deposited by glacial ice. Named for till exposed along ridgelines of Lone Mountain west of study area (Kline and Bundzzen, 1986). Unit lacks primary morainal topography and is covered by extensive deposits of silt, peat, and vegetation. Kettles are completely filled with sediment, and most kettlelike circular depressions are thermokarst features rather than glacial in origin. Thought to be Early or possibly middle Pleistocene in age (Kline and Bundezen, 1986). Bearing capacity considered low, due to silt and peat cover and permafrost; construction suitability unknown.

QdtpIm TILL OF PRE-LONE MOUNTALN GLACIATION-Isolated patches of unconsolidated to weakly cemented, diamicion largely recemented by calcite-forming tillite. Forms elongate, isolated patches of highly modified till up to 13 miles $(20 \mathrm{~km})$ beyond the known limits of Lone Mountain glaciation. No morainal topography recognized; unit is largely covered by 10 to $34 \mathrm{ft}(3$ to $10 \mathrm{~m}$ ) thick silt and peat bogs, and climax vegetation. May correlate with deformed till and outwash (QTg) of Big Saimon Fork glaciation. which is regarded as late Teriary to earliest(?) Pleistocene in age (Kline and Bundtzen, 1986). A less plausible correlation would assign Qdtplm to an earlier stade of the Lone Mountain glaciation. Unit Qdrplm is everywhere frozen, except where Holocene streams dissect till. Suitability for construction materials or bearing strength is untested and unknown. 


\section{SEDIMENTARY AND VOLCANIC ROCKS}

QTg CONSOLIDATED TILL AND OUTWASH-Weakly to well cemented diamicton, interbedded with crudely stratified outwash, which contains local and exotic lithologies. Faceted cobbles and striations on some cobbles and boulders suggest glacial transport for some of unit. Although outcrops are weathered, some crude stratification is present in outcrop, and is clearly visible with phoio-geologic analysis. Regional tilting to the souch reaches a maximum of 12 degrees, and is slightly disconformable with underlying Tertiary coal-bearing group units (Tcg, Ts). Although absolute age control is lacking, we correlate unit QTg with the Nenana Gravel exposed along the north flank of the Alaska Range, which is interpreted to be glacial outwash and tillite of Pliocene-Pleisrocene age (Wahrhaftig and others, 1969; Thorson, 1986). Kline and Bundtzen (1986) regarded unit QTg as drift of Late Tertiary(?) Big Salmon Fork glaciation after exposures on Big Salmon Fork in northeast corner of study area.

Tcf FELSITE CONGLOMERATE-Thick-bedded, poorly indurated, orange-weathered, light brown granule, cobble conglomerate that contains up $t 050$ percent clasts of felsic igneous rocks. Unit is crossbedded in a few places and dips slightly to moderately northwest where exposed. Overlies Ts unit below. Minimum thickness of $1,000 \mathrm{f}(300 \mathrm{~m})$ in western part of study area. Judged to be correlative with the coal-bearing group in the Nenana coal field (Wahrhaftig and others, 1969) of Oligocene-to-Miocene age.

Tcg COAL-BEARING SANDSTONE, SHALE AND CONGLOMERATE-Thin-to thick-bedded, poorly to moderately indurated, buff-weathered, gray-brown, granule, cobble conglomerate, minor sandstone, and interbedded dark gray carbonaceous shale and coal. Conglomerate clasts are moderately sorted, subangular to rounded, and consist mainly of quartz (20 to 40 percent), volcanic rock fragments (up to 20 percent), and sedimentarylithic fragments ( 30 to 70 percent). Matrix ranges in size from silt to granules. Beds are both massive and cross-stratified, and dip steeply to vertically in exposed canyon walls. Unit is estimated to be $4,790 \mathrm{ft}(1,460 \mathrm{~m})$ thick along Windy Fork. Solie and Dickey (1982) reponed that 20 to $65 \mathrm{ft}(6$ to $20 \mathrm{~m})$ thick shate-coal sections from Windy Fork to Middle Fork contain low rank, thin bituminous coal beds showing British Thernal Unit (btu) values ranging from 7,587 to 11,742. Eocene to Oligocene pollen reported during Allantic Rich field Company investigations of coal-bearing strata on Windy Fork (unpublished repon, 1980); however, unit Tcg was correlated by Dickey (1984) with unit Ts, which is considered to be pre-Middle Eocene in age (see below). Hence unit Tcg may range in age from Late Paleocene(?) to Oligocene. We correlate unit Teg with similar coal-bearing units in Tonzona River area about 38 miles $(60 \mathrm{~km})$ northeast of Windy Fork area (Sloan and others, 1979). Some unconsolidated conglomerate beds might be excellent sources of sand and gravel.

Ts SANDSTONE AND SHALE-Thin- to thick-bedded, moderately indurated, red-brown weathered, buff, medium-grained, lithoquartzose sandstone interbedded with poorly indurated, laminated, fissile, carbonaceous shale and fine sandstone. Sandstone clasts are moderately sorted, subangular to rounded, and consist of argillite (30 to 60 percent), quarz (20 to 50 percent), carbonaceous material (up to 20 percent), and volcanic lithic fragments (up to 10 percent). Plant-bearing mudstone intruded locally by Middle Eocene dike ( $45.5 \mathrm{Ma}$; Solie and others, 1991): hence, age is considered to be pre-Middle Eacene.

TCI LIMESTONE CONGLOMERATE-Thick- to thin-bedded, moderately indurated, green-gray granule conglomerate exposed in fault sliver near Khuchaynik Creek. Unit contains up to 80 percent limestone clasts; the remainder composed of basalt and lithic fragments. Matrix size ranges from clay to sand, and beds appear structureless. Although compositionally distinct. Tel crnps out near units Ts and Tcg, and is correlated with them. Hence age is considered to range from Late Paleocene(?) to Oligocene.

\section{SHEEP CREEK, WINDY FORK AND TERRA COTTA VOLCANIC FIELDS} (This study)

TVs VOLCANICLASTIC SANDSTONE AND LACUSTRINE SUT-Brown to gray, medium- to fine-grained volcaniclastic sandstone that has a distinctive $50 \mathrm{ft}(15 \mathrm{~m})$ thick section of flora-rich paleosols and finely laminated, varved shales of probable lacustrine origin. A plant fossil assemblage rich in Metasequoia cuneata 
and Glyprostrobus europaeus (Bundtzen and others. 1982) is judged to be of Eocene age. Unit Tvs in upper Sheep Creek direckly overlies a progressive sequence of volcanic flows, proximal vent facies, volcanic breccias, and air-fall tuff, and may represent lacustrine and related sediments deposited in a crater lake (?) during the waning stages of volcanism in the Sheep Creek volcanic field. Very non-resistant and at best forms handspecimen sized rubble.

Tvt

INTERMEDIATE TO FELSIC AIR-FALL TUFF-Composite unit of light- to medium-green-gray, well laminated medium to very coarse grained, crystal-rich, air-fall tuff. Sheep Creek volcanic field includes at least four 50 to $80 \mathrm{fi}(15$ to $25 \mathrm{~m}$ ) thick air-fall sequences consisting of a $10 \mathrm{ft}(3 \mathrm{~m})$ thick basal layer of angular, boulder-to-cobble-sized ejecta fining upward 10 well laminated, pebble $\sim$ to sand-sized tuff. Also includes poorly exposed welded(?) tuffs along mountain front south of St. Johns Hill. In Sheep Creek drainage unit is probably a vent facies near a volcanic center. Individual air-fall sequences are covered by paleosols rich in petrified wood. dicotyledon leaves, and Metosequoia. In the Sheep Creek volcanic field, unit Tvt underlies lacustrine-bearing deposits (Tvs), but overlies mafic and intermediate flows (Tvm, Tva). Total thickness is estimated to be $590 \mathrm{fl}(180 \mathrm{~m})$ on Sheep Creek. Nonresistant and forms weathered, naggy rubbie.

Tva ANDESITE FLOWS AND LAPILLI TUFF-Dark-gray to green-gray andesite flows and locally banded (red, green, purple, bleached) lapilli tuff. Groundmass of flows is aphanitic to fine-grained intersertal and consists of andesine accompanied by abundant hornblende, clinopyroxene, opaque minerals, and rare quartz. Euhedral homblende phenocrysts to $5 \mathrm{~mm}$ long are common. Propylitization is pervasive, producing carbonate, chlorite, and epidote. Lapilli tuff fragments are extensively chloritized. In Windy Fork volcanic field, Tva unit yielded whole rock K-Ar age of 37.1 Ma (Solie and others, 1991); Tva unir in Sheep Creek and Terra Cotta volcanic fields are unknown. Estimated to range from 65 to $260 \mathrm{ft}(20$ to $80 \mathrm{~m})$ thick at Windy Fork, Sheep Creek, and Terra Cotta volcanic fieids. Moderately resistant and forms blocks to $3 \mathrm{ft}$ ( $1 \mathrm{~m}$ ) in diameter.

TVd MASSIVE DACITE-Light- to medium-gray, porphyro-aphanitic, homblende-bearing massive dacite of Terra Corta volcanic field. Does not contain breccias and sedimentary rock fragments typical of underlying (Tvid and $\mathrm{T} v \mathrm{vd}$ ) units. Whole-rock $\mathrm{Ar}^{+0}-\mathrm{Ar}^{39}$ minimum age of $31.3 \mathrm{Ma}$ obtained from near stratigraphic top of Terra Cotta voicanic field (Solie and others, 1991). Resistant and forms large angular blocks to $10 \mathrm{ft}$ (3 m).

Tvld LAPILLI DACITE-Light gray to bleached white with yellowish staining, lacally banded (purple. white), lapilli dacite and tuff. Lapilli fragments are commonly chloritized. Thickness and age unknown but part of Terra Cotta volcanic field that ranges in age from 31.3 to $41.3 \mathrm{Ma}$ (Solie and others, 1991). Moderately resistant and forms flaggy, weathered rubble.

Trud VENT FACIES DACITE-Very distinctive, light gray, distinetly tan weathering, homblende and K-spar-rich, propylitically altered dacite containing very abundant angular clasts of sedimentary rocks (mainly Kahilena terrane flysch) that comprise up to 30 percent of groundmass. Clasts range in size from approximately 1 inch to $10 \mathrm{ft}$ (several centimeters $103 \mathrm{~m}$ ) in diameter, suggesting unit represents vent facies or magma chamber that stoped upward through the enclosing Kahiltna terrane flysch during eruptive cycles in Terra Cotta volcanic field. Estimated to be $1.300 \mathrm{fr}(400 \mathrm{~m})$ thick where exposed in cliff walls along South Fork, McGrath A-1 Quadrangle. Resistant and forms large blocks to $10 \mathrm{ft}(3 \mathrm{~m})$ in diameter.

TVab ANDESITE BRECCIA-Medium-gray, purple-hued weathering, porphyritic. pyroxene andesite containing distinctive zones of pyroclastic breccia consisting of in situ andesite fragments averaging 2 inches $(5 \mathrm{~cm})$ in diameter; exclusively mapped in Terra Colta volcanic field. Some agglomerate interbedded in andesite breccia flows. Groundmass of flows is aphanitic to intersertal and consists of andesine, homblende, clinopyroxene, and opaque minerals, similar to mineralogy of Tva flows mapped in other volcanic fields of map area. A $\mathrm{r}^{40}-\mathrm{Ar}^{39}$ hormblende age of $41.1 \mathrm{Ma}$ determined from andesite breccia near base of Terra Cotza volcanic field. Resistant and forms large blocky rubble.

Tvls LAPILLI RHYODACITE-Light- to medium-gray, porphyro-aphanitic, K-spar-rich shyodacite flows containing conspicuous layers of purple, green, and red lapilli tuff beds 5 to $15 \mathrm{ft}(1.5104 .5 \mathrm{~m})$ thick. Lapilli tuff is composed of chlorite-rich fragments 4 to $45 \mathrm{~mm}$ long of no preferred shape: matrix is mainly silt-sized $\mathrm{K}$-spar and quartz. Unit Tvir forms a prominent $800 \mathrm{ft}(245 \mathrm{~m})$ thick pile near southern end of Terra Cotta 
volcanic field near the co-magmatic(?) Hartman Pluton (Tgd), which suggests that the Hartman Pluton and Terra Cotta volcanic field might constizute a volcanic-plutonic complex similar to those mapped in the Kuskokwim mineral belt of southwestem Alaska (Bundtzen and Miller, 1997). Somewhat resistant, and forms moderately blocky rubble.

Tvgt GREEN TUFF-Distincty mid- to dark-green, fine to medium grained, ash flow(?) tuff containing very minor blocks of darker green, altered agglomerate composed of rounded clasts to 4 inches $(10 \mathrm{~cm})$ in diameter. Unit forms a useful marker bed in Terra Cotta volcanic field that can be traced throughout the lower porion of the volcanic succession stratigraphically above the basal andesite breccia flows for at least 2.5 miles $(4 \mathrm{~km})$ of strike. Estimated to be 35 to $45 \mathrm{ft}$ (11 to $14 \mathrm{~m}$ ) thick; generally nonresistant.

Tvl LAHAR DEPOSITS-Medium- to dark-green-gray, very coarse grained lahar deposit. Unit consists of chaotic mixtures of volcanic-derived mud, andesite flow fragments, epiclastic breccia, and blocks of the Kahiltna terrane llysch. Tvl was deposited in debris flows at the base of the Terra Cotta volcanic field. Estimated to be $65 \mathrm{fl}(20 \mathrm{~m})$ thick; generally nonresistant.

TYf FELSIC TUFF AND FLOWS-Bleached to lighr-gray, locally banded, hypocrystalline rhyolite tuff and flows: consists of sericitic alkali feldspar and resorbed, fine-grained quartz phenocrysts in an aphanitic quartzofeldspathic groundmass. Devisrification sperulites common. May include a band of welded(?) weff on north end of Sheep Creek volcanic field. Unit occurs at various stratigraphic positions in the Windy Fork. Sheep Creek, and Terra Cotta volcanic fields; hence no stratigraphic position implied. Estimated to range in age from $31.31048 .9 \mathrm{Ma}$ or the collective age range of all volcanic units within this group. Tuf ranges in thickness from $11510500 \mathrm{ft}$ ( 35 to $152 \mathrm{~m}$ ). Generally resistant and forms large elongate blocks in scree slopes.

TVm BASALT AND BASALTIC ANDESITE-Dark gray to maroon, locally porphyritic, olivine bearing, augite basalt and basalsic andesite hows. Groundmass frequently altered to chlorite, epidote, and secondary opaque minerals. Columnar jointing readily expressed in outcrops. Occurs as both an interlayer sandwiched between andesite flows and at the base of the volcanic flows of the Sheep Creek volcanic field. In Sheep Creek volcanic field, unit has yielded four $\mathrm{K}$-Ar ages ranging from $41.3 \mathrm{Ma}$ (minimum age) to $48.9 \mathrm{Ma}$ (Bundtzen and others, 1982; Solie and others, 1991).

\section{VELESKA LAKE VOLCANIC FIELD}

(This study)

TKvd DACITE FLOWS AND DIKES-Light- 10 medium-gray, aphanitic to porphyro-aphanitic, chloritized homblende dacite flows: flow banding unconmon. Located west of Veleska Lake, and intruded by numerous hormblende granodiorite dikes of similar appearance and hence lumped with TKvd. Unit is similar to volcanic rocks of similar composition in Terra Cotta volcanic field described above, except that TKvd appears to be more altered. One K-Ar homblende age of $65.8 \mathrm{Ma}$ determined from flow section near base of unit. Resistant and forms blocky rubble on scree slopes; estimated to be $1,150 \mathrm{ft}(350 \mathrm{~m})$ thick.

TKYf RHYOLITE TUFF-White- to light-gray, locally banded, hypocrystalline rhyolite; typically consists of sericitic alkali feldspar and resorbed fine-grained phenocrysts, and angular glassy shards. Occurs near the top of unit TKvd. Age and thickness unknown; nonresistant and forms small, flaggy rubble.

TKvm BASALTIC ANDESITE-Medium-gray-green, fine-grained, augite-rich basaltic andesite and minor andesite flow breccia mapped near the base of Veleska Lake volcanic field near Veleska Lake. Stmilar to both Tvm and Tva of younger volcanic fields, except always more ubiquitously altered. Estimated to be about $130 \mathrm{ft}(40 \mathrm{~m})$ thick; moderately resistant where not brecciated.

TKVt AIR-FALL TUFF OF INTERMEDIATE COMPOSITION-Light- to medium-green-gray, well laminated, crystal tuff consisting of 3 to $14 \mathrm{ft}(1 \mathrm{to} 4 \mathrm{~m})$ thick beds; deposits contain pebble-to sand-sized clasts. In upper Tin Creek. TKve contains $1 \mathrm{ft}(30 \mathrm{~cm})$ thick paleosol, rich in undated plant fossils. Estimated to be $80 \mathrm{ft}$ $(25 \mathrm{~m})$ thick; nonresistant and weachers to sandy scree. 


\section{KAHILTNA TERRANE \\ [Mapped southeast of Tatina River Fault]}

KIsh SANDSTONE AND SHALE-Medium- to very dark-gray, fine-grained, lithic sandstone, siltstone, and shale; comprises about 75 percent of the Xahilena terrane. From a distance, color of unit is almost black-earning it the colloquial term "Black Crap" clastics. Contains angular to subangular clasts of chert and quart (40 percent), lithic fragments ( 25 percent), volcanic clasts ( 25 percent), feldspar ( 5 percent), and white mica and opaques (5 percent). Flutes, ripple marks, and flame structures are locally abundant, and sand intervals contain cyclic, graded Bouma Tbcde intervals (after Mutti and Ricci Lucchi, 1972), which indicate deposition in turbidity currents. Sand-to-shale ratios average 1:3. In McGrach B-1 and A-2 quadrangles, unit includes collections of Inoceramus murgalensis of the Neocomian stage and Inoceramus peltiformis pochialaynen of the Hauterivian stage-both indicating an Early Cretaceous age (Bundtzen and others, 1987; this study). Unit is complexly deformed, which prevents an accurate thickness estimate. Unit $\mathrm{KJ}$ sh is nonresistant and forms flaggy scree.

KJs COARSE SANDSTONE AND MLNOR SUTSTONE-Medium-gray to distinctly tan-weathered, lithic sandstone containing clasts of volcanic rocks (25 percent), sandstone and shale (25 percent), granitic(?) rocks (15 percent), quartz (20 percent), and lime-rich sediments (15 percent). Flute casts and ripple marks are common, and sand intervals contain cyclic graded Bouma Tabc intervals (after Mutti and Ricci Lucchi, 1972) up to $6.5 \mathrm{ft}(2 \mathrm{~m})$ thick. Sand-\{0-shale ratios average 5:1. Unit KJs is interbedded with KJsh, which contains Early Cretaceous pelecypods. Thickness poorly constrained but at least $1,000 \mathrm{ft}(300 \mathrm{~m})$ in McGrath B-1 Quadrangle. Moderately resistant and forms angular scree to 8 inches $(25 \mathrm{~cm})$ in diameter.

KJC PEBBLE TO BOULDER CONGLOMERATE AND MINOR SANDSTONE-Light-gray, tan weathered, pebble to boulder conglomerate. Pebbles are sub-angular to rounded clasts of granite and quartz diorite ( 30 percent), in situ lithic sandstone and shale (25 percent), quartz ( 20 percent), and mixed volcanic-lithics ( 25 percent). Some massive conglomerate layers measured $80 \mathrm{ft}(25 \mathrm{~m})$ thick south of Tauna River. Inoceramus murgalensis of Early Cretaceous age found in one KJe locality. Two graded Bouma Tab intervals (after Mutti and Ricci Lucchi, 1972) recognized; otherwise, unit does not contain turbidiry current deposits. Sand-shale ratios average 10:1. Thickness of $1,150 \mathrm{ft}(350 \mathrm{~m})$ estimated south of Tatina River, bur highly variable along strike. Unit crops out in several bands in Kahiluna terrane, which are interpreted to be the same honzon repeated by largescale sub-isoclinal folds. Resistant and forms large $3.3 \mathrm{ft}(1 \mathrm{~m})$ long blocky rubble in landslide deposits and cirque debris.

\section{MCKINLEY TERRANE \\ [Mapped north of Denali-Farewell Fault]}

$\mathrm{KJm}$ SLATE AND METASILTSTONE-Very thin-bedded, fissile, nusty-brown-weathered, black słate, metasiltstone, micaceous metasandstone, and rare silty limestone turbidite. Minor quartz-carbonate veinlets parallel cleavage. Mesozoic radiolaria and megafossils were collected in unit exposed in Talkeetna C-6 Quadrangle (Reed and Nelson, 1980; Jones and others, 1983). Non-resistant. Thickness unknown due to intense structural deformation.

\section{PINGSTON TERRANE \\ [Mapped north of Denali-Farewell Fault]}

Trls LIMESTONE AND SHALE-Thin-bedded, medium gray quarzitic limestone; gray, silfy limestone, and shale. Basal beds are predominantly gine-grained, gray sandsione and siltstone and subordinate cherty limestone that contains black chert clasts. Unit is commonly cut by thin quarz-carbonate veins. Late Triassic Monotis sp. pelecypod collected from limestone-shale horizon near eastern edge of map area (Kline and others, 1986). Unit correlates with the Pingston terrane exposed in the Mount McKinley region 90 miles (155 km) northeast of the study area (Jones and others, 1983). Thickness estimated to be $330 \mathrm{ft}(100 \mathrm{~m})$ in map area; moderately resistant where quartz-rich lime beds exceed 50 percent of unit. 


\title{
YUKON-TANANA TERRANE \\ [Mapped north of Denali-Farewell Fault]
}

uPzS VOLCANOGENIC PHYLLITE-Dark gray-green to distinctly maroon, pyrise-rich volcanogenic phyllite cut by thin quanz-carbonate veins. Stratigraphic relationships imply that uPzs overlies uPzc; however, no age control is available. Nonresistant and forms flaggy debris on scree slopes. Thickness unknown but less than $660 \mathrm{ft}(200 \mathrm{~m})$.

¿Pze PHYLLITIC CHERT AND SRICEOUS PHYLLITE-White-weathered, gray-green, banded phyllitic ribbon chert. Pennsylvanian through Permian radiolaria identified at one locality in map area (Kline and others, 1986). Radiolaria and conodonts of Mississippian through Permian age collected by Jones and others (1983) immediately east of the map area. In one area, uPzc is fault-bounded berween Trab on the south and $\mathrm{KJm}$ on the north; it apparently stratigraphically underlies Trls near the head of the 8ig Salmon Fork. Gilber and Bundtzen (1984) suggested that uPzc and uPzs are in the upper part of the Yukon-Tanana terrane, a major tectono-seratigraphic terrane underlying much of interior Alaska north of the Denali-Farewell faule. Thickness estimate not possible due to strictural deformation. Generally nonresistant due to high phyllite content.

\section{FAREWELL COMPOSITE TERRANE}

\author{
MYSTTC SUBTERRANE \\ (Mapped north and south of Derali-Farewell Fault)
}

Tatina River Volcanics (This stady)

IJs PHOSPHATIC SHALE AND GREEN VOLCANICLASTIC SANDSTONE-Medium- to very-dark-gray. distinctly bleached bluish-white, phosphatic shale (25 percent); green, medium grained, concretion-rich. volcaniclastic sandstone ( 60 percent); and minor tan chert-cobbie pebble conglomerate (15 percent). Contains Entolium sp. and Eopecten(?) sp. of Jurassic age (J.W. Miller and W.P. Elder, written commun., 1984) in Tatina River area, McGrach B-1 Quadrangle. Probably correlative with Arietitid ammonite-bearing phosphatic beds of Lower Jurassic age (Sinemurian stage) that was mapped at the top of the Mystic subtersane in the Talkeetna C-6 Quadrangle (Reed and Nelson, 1980; J.W. Miller and W.P. Elder, written commun., 1984). Estimated to be $150 \mathrm{ft}(45 \mathrm{~m})$ thick; nonresistant due to high shale content.

Trab PILLOW BASALT AND GABBRO-Dark green-gray, massive, aphanitic to medium-grained, olivineclinopyroxene rich, pillow basalt, olivine diabase and gabbro sills, and mafic agglomerate. Composition of mafic sills ranges from picrite to diabase, but all are titanium rich and tholeitic. Pillow structure well developed locally, but basalts and agglomerate frequently altered to serpentinite, or orange silica-carbonate rock; unit is extensively chloritized. Fossils of Late Triassic age found in several localities of unit Trs (see below), which interfingers with Trab. Unit Trab appears on both sides of the Denali-Farewell fault, where it overlies the clastic-rich Sheep Creek Formation (PDs). Trab contains very high copper content regionally (average is $307 \mathrm{ppm}$, from nine analyzed samples). Estimated to be 500 to $660 \mathrm{ft}$ (152 to $200 \mathrm{~m}$ ) thick. Very resistant when fresh, but nonresistant where altered.

Trs SHALE, COARSE VOLCANICLASTIC SANDSTONE, AND CHERT-Tan to greenish-gray, buff to orange weathered. pebble rich, immarure conglomerate, coarse volcaniclastic sandstone, distinctly brown silty shale, and light gray, green, and black chert. Interbedded with pillow basalt and gabbro (Trab) described above. Unit Trs contains Monotis subcircularis in McGrath B-1 Quadrangle and Halobia cf. fallax or H. cf. condillerana in the Lime Hills Quadrangle; both indicate the late Early-to-early Late Norian stage of the Late Triassic (Bundtzen and others, 1994: N. Silberling, written commun., 1984). Unit Trs varies from 130 to $330 \mathrm{fr}$ (40 to $100 \mathrm{~m}$ ) thick; nonresistant due to flaggy nature of weathered sedimentary rocks.

\section{Sheep Creek Formation (This study)}

PDS SUBLTTHIC SANDSTONE, LIMESTONE-CHERT CONGLOMERATE, AND MINOR LIMESTONEMedium-gray, distinctly brown-red weathered. medium- to coarse-grained, sublithic sandstone and pebble 
conglomerate that contains clasts of limestone (40 percent), chert (20 percent), lithic fragments ( 15 percent), volcanic clases ( 5 percent), and polycrystalline quartz (20 percent). Clastic unirs lack detritsl white mica and calcite cement that is abundant in Dillinger subterrane lithologies, but instead contains plant fossils. which are absent in the latter. Rip-up clasts are very common and graded bedding is present as Boumg Tab intervals (after Mutti and Ricci Lucchi. 1972) indicating a coarse turbidite facies. Sand-to-shale ratios in main clastic section average about 8:1. However, the limestone chert conglomerate, which caps the PDs section, lacks graded beds, and exhibits distinct channeling suggestive of fluvial deposition. Calcareous sandstones from three localities midway in the PDs section of the McGrath B-2 Quadrangle contain fusilinids that have an advanced "schwagerinid wall", which indicates a Late Pennsylvanian to possibly Permian age (R.C. Douglas, written comm., 1983). Two zones of limestone concretions in black shale above the massive algal limestone (IDI) near the base of unit in the Sheep Creek area contain: (1) Palmatolepis sp. and Polygnathus sp. conodonts of Frasnian (Late Devonian) age (M.J. Orchard, written comm., 1991); and (2) Dendrostrella sp. cf. D. trigemme (coral) of Late Eifelian and Givetian (Middle Devonian) age (W.A. Oliver, written commun., in Bundtzen and others, 1982). Hence existing evidence suggests an age range for PDs from Middle Devonian to Permian. Reed and Nelson (1980) described Middle(?) Pennsylvanian plant fossils from non-marine, conglomerate-rich Mystic subterrane rocks at Mount Dall in the western Talkeetna Quadrangle, which we correlate with the limestone-chert conglomerate near the stratigraphic top of the PDs unit. Bundtzen and others (1994) mapped a thin, shallow water limestone, interbedded midway within the PDs unit, that contains Late Mississippian fossils in the central Lime Hills Quadrangle. Unit is estimated to be 1,640 $\mathrm{fr}(500 \mathrm{~m})$ thick in the Sheep Creek area. Generally nonresistant due to weathering.

MASSIVE ALGAL LIMESTONE-Massive, shick-bedded, medium-gray limestone, rich in algal laminations and Amphipora sp. Varies greatly in thickness along strike from 33 to $660 \mathrm{ft}(10$ to $200 \mathrm{~m})$ reflecting rapid thinning and thickening of a shallow water, lagoonal carbonate facies. Amphipora-bearing lime mudstone collected in IDI unit in McGrath B-2 Quadrangle yielded Ozarkodina sp. indet. or Kockelella sp. indet. of Middle Silurian-to-early Devonian age (A.G. Harris and J.E. Repetski, written commun., 1989). Stratigraphically underlies Middle and Late Devonian fossil localities in PDs unit (see above): units IDI and IDd form base of Mystic subterrane in Sheep Creek area south of Denali-Farewell fault. Locally very resistant and cliff-forming; forms large blocks at base of cirques.

IDd DOLOMITE-Light gray, dolomitized, algak(?) limestone similar in appearance to IDI; unit exhibits complete dolomitization. No age control available, but thought to be correlative with $1 D \mid$ unit. Very resistant due to dolomitization. About $80 \mathrm{ft}(25 \mathrm{~m})$ thick.

\section{St. Johns Hill Formation (This study)}

uDI MASSIVE MICRITIC LIMESTONE-Medium-gray, massive- to thick-bedded, micritic limestone that contains crypto-algal laminations, thin, black chert partings, and dolomitic nodules. Unit contains an abundant and diverse fauna of rugose corals, brachiopods, and pelecypods on St. Johns Hill and in the Farewell Mountain area, which indicate a Frasnian (early Late Devonian) age (Bundizen and others, 1982). Unit varies greatly in thickness from 3.3 10 $660 \mathrm{ft}$ ( 1 to $200 \mathrm{~m}$ ), and in some areas is apparently absent from the section. We interpret this to reflect the rapid thinning and thickening of a shallow water, reef carbonate facies. Unit uDi underlies PDs unit on Farewell Mounsain. Resistane due to massive nature of limestone. Unit of identical age and character described by Reed and Nelson (1980) neas base of Mystic subterrane south of the DenaliFarewell fault in Talkeetna Quadrangle.

Dls LIMESTONE AND MNOR SILTSTONE-Brown to terra conta. micaceous, slightly pýritic, thirly laminated mudstone, siltstone, limestone, and medium-grained lithic sandstone that underlies $u D l$ on St. Johns Hill in McGrath B-2 Quadrangle. Locally contains thin black chert partings. Tentatively correlative with basal portion of PDs unit; it may be a deeper water facies of the algal limestone (IDI) exposed on the south side of the Denali-Farewell fault. 


\section{DILLINGER SUBTERRANE \\ [Mapped south of Denali-Farewell Fault]}

Barren Ridge Limestone (Churkin and Carter, 1996)

DSI CALCARENITE, CALCAREOUS SILTSTONE, AND LAMINATED LIMESTONE-Thin- to thick-bedded, buff to orange-weathered, light- to medium-gray, phyllitic calcarenite, thin-bedded orange to buff siltstone. and light gray silty limestone all in approximately equal amounts. Basal portion of unit is more limestone rich. Contains channelized limestone breccis bodies, limestone conglomerate, and graded coarse pebble sandstone. Fiver grained clastics exhibit both stacked foreset beds and Bouma Tbced intervals: we interpret unit to represent proximal turbidite or foreslope depositional facies. Conodonts (Bundtzen and others, 1994; this study) range from Late Silurian to Late Devonian; however. Blodgetn and Gilbert (1992) reported conodont fauna of Lochkovian to Pragian age (Early Devonian) from unit DSI in Lime Hills D-4 Quadrangle. Deformation makes tnie thickness estimates difficult, but unit is approximately $1.000 \mathrm{ft}(300 \mathrm{~m})$ in map area. Resistance variable due to heterogeneous nature of unit

Terra Cotta Mountains Sandstoze (Churkin and Carter, 1996)

USSI THIN-BEDDED CALCAREOUS SANDSTONE, GRAPTOLITIC SHALE, AND SRTY LIMESTONEThin-bedded, gray to tan, micaceous sandstone, silty limestone, and dark gray graptolitic shale. Clast compositions indicate feldspathic litharenite (Folk, 1968), containing up to 6 percent white mica. Flute casts and ripples observed locally. Carbonate content estimated to be about 15 percent. Probably equivalent to Upper Limestone member of Churkin and Carter (1996). Sand-ro-shale ratios average about 2:1. Monograptus cf. M. pseudodubius, Lobograptus progenitor, and Pristiograptus cf. P. tumescens from the Neodiversograptus nilssoni zone, Ludlovian stage (Late Silurian) identified (Bundtzen and others, 1982; Bundtzen and others. 1994). Unit uSsl is the top of the Terra Cotta Mountains Sandstone as defined by Churkin and Carter (1996). Estimated to be 250 to $330 \mathrm{ft}$ ( 75 to $100 \mathrm{~m}$ ) thick. Relatively nonresistant and forms flaggy scree on slopes.

mSvs PHYLLITE, VOLCANICLASTIC SANDSTONE, AND CHERT-Thin-bedded, complexly folded, maroon 10 green phyllise, medium-green, medium-grained volcaniclastic sandstone. and green-gray chert. Appears to be stratigraphically above mSI unit, and under uSsl unit on Tunis Mountain near Veleska Lake. Sands composed of andesite and felsite grains (40 percent). quartz (20 percent). framework grains (20 percent), and chert (20 percent). Some thin sections suggest the presence of thin $5 \mathrm{~cm}$ thick ash(?) layer in silty sand beds. Unit can be traced for about 5 miles $(8 \mathrm{~km})$ of strike but was not mapped beyond Tunis Mountain area. Estimated to be a maximum $130 \mathrm{ft}(40 \mathrm{~m})$ thick. Nonfossiliferous, but conserained by Wenlockian and Ludlovian graptofite collections below and above mSvs outcrops respectively. Nonresistant; forms loose rubble on hill slopes and does not crop out well.

mSI ARGLLACEOUS GRAPTOLITIC LIMESTONE-Medium- to dark-gray and brown weathered limestone containing graptolite-bearing silty sandstone intervals. Unit forms distinctive wall-\}ike outcrops throughout map area, and is interbedded with the larger mSs clastic unit. Generally equivalent to Middle Limestone nember of Churkin and Caner (1996). Graptolite-bearing beds in mSl have yielded Pristiograptus dubious, Monograpius cf. $M$. Iudensis, and Monograpius digizalus that represent two graptolite zones of the upper Wenlockian stage of the Silurian (Churkin and Carter, 1996; Bundzzen and others, 1987: Bundtzen and orhers, 1982). However, unit mSl, as depicted on plate 1, may also include locally the lower limestone member of Churkin and Carter (1996), which is stratigraphically lower than limestone containing the $P$. dubius and $M$. ludensis graptolite zones (see mSs below). Unit mSI has also yieided orthoconic nautiloid ceghalopods, cardiolid bivalves, and ribbed atrypacean brachiopods, all nondiagnostic, but probably of Silurian age (Bundzen and others 1987,1994 ). Unit $\mathrm{mSl}$ ranges widely in thickness, which varies from 80 to 500 ft (25 $10152 \mathrm{~m}$ ): maximum thicknesses are obtained in the eastem portion of the quadrangle, but unit becomes very thin near Big River on the western edge of the map area. Unit is resistant and forms prominent cliffs and exposures throughous map area. 
mSs FELDSPATHIC-LITHIC SANDSTONE, LIMEY SILTSTONE, AND ARGILLITE-Medium olive gray to terra corta, medium- to coarse-grained. thin-bedded to massive, calcareous lithic sandstone, and siltstone containing local gray shale intervals and minor pebble conglomerate beds. Major components are polycrystalline quartz ( 25 percent), chert (20 percent), detrital carbonate ( 15 percent), matrix (15 to 20 percent), altered feldspar (10 percent), and white mica and opaques (10 percent). Petrography of representative samples indicate that sands in unit are feldspathic litharenites after Folk (1968) with a recycled orogen provenance (Dickinson and Suczek, 1979). Sandstones contain well developed oscillation ripples, flute casts, graded bedding with Bouma Tabcd intervals (after Mutti and Ricci Lucchi, 1972), and planar crossbedding indicating deposition in a mid-fan(?) turbidite environment. Numerous paleocurrent measurements indicate bimodal N20-40E and S25-45W populations. Sand-to-shale racios average 10:1. Limey beds in lower mSs member that are thought to be equivalent to the Lower Limestone member of Churkin and Carter (1996) contain Monograptus aff. M. priodon, and Cyrtograpsus lundgreni which represent zones in the middle to early Weniockian stage of the Silurian. Unit $\mathrm{mSs}$ is estimated to range from 660 to $1.310 \mathrm{ft}(200$ to $400 \mathrm{~m})$ thick throughout the map area, and is the dominant unit of the Terra Cora Mountains Sandstone. Generally resistant especially the thick sandstone layers, which form blocky rubble on steep slopes.

\section{Post River Formation (Churkin and Carter, 1996)}

ISI BOUNDARY LIMESTONE-Thin, dark gray, fetid, laminated limessone with thin $(3 \mathrm{~cm}$ thick) silty sand layers, and thin interbeds of black cherty argillite. Contains Cyrtograptus centrifugus of $C$. centrifugus zone, earliest Wenlockian stage, late Early Silurian. Although only 34 to $80 \mathrm{fl}$ ( 10 to $25 \mathrm{~m}$ ) thick, 1Sl forms a distinctive marker unit between clastic dominated turbidites of Terra Cotta Mountains Sandstone and finer grained basinal facies of the Post River Formation-hence our term "Boundary Limestone." Nonresistant and does not always crop out.

SOsh GRAPTOLITIC SHALE, SILTSTONE AND CHERT-Medium- to dark-gray, fetid, fissile, isoclinally folded, carbonaceous shaie, siltstone. and black bioturbated, siliceous siltstone and chert. Very thin Bouma Tcde intervals (after Mutti and Ricci Lucchi, 1972) up to $10 \mathrm{~cm}$ thick occur locally but only make up a few percent of the unit. Distinctive sulfurous plumes in some outcrops readily distinguish SOsh from other fine-grained, clastic Dillinger subterrane units. In the northeastern portion of the map area, unit is composed of approximately 70 percent black chert and 30 percent fine-grained clastic rocks. West of South Fork, fine-grained clastic lithologies dominate, and chert is only a minor (less than 10 percent) component of the section. Thin $(<1 \mathrm{~m}$ ) bioturbated zones appear as silicified. brown-marbly textured zones where original bedding has been destroyed by burrowing organisms. Contains numerous graptolite fauna including I5 graptolite zones that represent tive of six Ordovician stages (Ashgillian stage graptolites not yet found) and most of the Landoverian stage of the Early Silurian, one of the most complete Ordovician-Lower Silurian graptotite successions in the world. Unit includes the Mudstone, Upper Siltstone, and Graptolite Canyon members of Churkin and Carter (1996). Unit SOsh is roughly equivalent to Road River Formation in east-central Alaska and Yukon, Canada. Unit SOsh is complexly deformed but estimated to range from 130 to $400 \mathrm{ft}$ (40 to $122 \mathrm{~m}$ ) thick. Very nonsesistant and frequently buried under vegetation and talus of more resistant units.

Lyman Hills Formation (This study; Bundezen and others, 1994)

OCIs SUTY LIMESTONE AND SHALE-Rhythmically layered, thin-bedded, orange to buff, light gray when fresh, limestone, silty shale. and light olive shale. Individual time units range from $51025 \mathrm{~cm}$ thick, and exhibit parallel and cross laminations. Shate and siltstone exhibit ripple-laminated structures with amplitudes of 5 to $70 \mathrm{~cm}$. Most distinctive sedimentary structures are stacked. wedge-shaped cosets in silty limestone. Some limestone beds contain thin Bouma Tede intervals (after Mutti and Ricci Lucchi, 1972). As defined here, unit includes the lower Siltstone member of the Post River Formation as originally defined by Churkin and Caner (1996), which contains the Adelograprus graptolite zone of the early Early Ordovician. Sample of silty limestone from core of Terra Cotta Anticline in McGrath A-2 Quadrangle yielded Teridontis nakamurai, which is part of the Cordylodus lindstromi zone, of late Late Cambrian-to-early Early Ordovician age (D. Podson, written commun., 1983). We have named the OCls unit, which ranges from 2,130 to $3.300 \mathrm{ft}$ (650 10 $1.000 \mathrm{~m}$ ) in thickness, the Lyman Hills Formation after extensive exposures in the Lyman Hills immediately 
west of the map area (Gilbert, 1981). We tencatively correlate OCls with the Rabbit Kettle Formation in Yukon, Canada, a Cambro-Ordovician basinal facies underlying the Road River Formation (Gordey and Anderson, 1993). Relatively nonresistant due to its thinly bedded nature.

\author{
MINCHUMINA SUBTERRANE \\ [Mapped north of Denali-Farewell Fault]
}

PzpCs METAQUARTZITE AND CALCAREOUS PHYLLITE-Lighi- to medium-gray, fine- to coarse-grained, metaquartzite, quarkz-feldspar "grit", calcareous phyllite. and minor metachert exposed in extreme northeast corner of map area. Presence of quarz +albite+chlorite mineral assemblage in phyllite indicares PzpCs experenced lower greenschist metamorphic conditions. Unit is included in the Telida subterrane of the Minchumina subtertane, which is assigned a Late Proterozoic-to-Paleozoic age (Patton and others, 1994); however, PzpCs might also correlate with the Yukon-Tanana terrane (see above). Thickness unknown due to poor exposures. Quartz-rich "grits" locally resistant and produce blocky rubble to 20 inches $(50 \mathrm{~cm})$ in diameter.

\title{
INTRUSIVE ROCKS AND HORNFELS
}

\section{TERTIARY INTRUSIVE ROCKS AND HORNFELS}

Tia ANDESITE-TRACHYANDESITE SILLS AND DIKES-Green-gray, fine-grained, hypidiomorphic-granular. porphyritic andesite dikes less than $65 \mathrm{ft}(<20 \mathrm{~m})$ thick; local variety-granodiorite. Consists of variable amounts of homblende, alkali feldspar, biotite, and clinopyroxene. Alteration to chlorite and carbonate is common. Contact effects with enclosing host rocks include metalliferous skams at Tin and Bowser creeks and intense brecciation near Windy Fork (Bundtzen and orhers, 1982, 1987). Five K-Ar ages from Tia dikes range from 20.9 to $39.3 \mathrm{Ma}$ (Solie and others, 1991). Resistant; forms ribs protruding through layered rocks.

Tif FELSIC SLLS AND DIKES-Felsic dikes and sills up to $16 \mathrm{ft}(5 \mathrm{~m})$ thick cul layered rocks in Bowser Creek and Sheep Creek areas. Generally light pinkish tan to white; aphanitic- to fine-grained; rarely medium-grained. Exhibits hypocrystalline as well as holocrystalline textures and contains phenocrysts of plagioclase and alkali feldspar. Unit locally rich in sulfides. Although no age control is available, Tif usually cuts Tim dikes and sills. Somewhat resistant but less so than Tia dikes and sills.

Tim MAFIC SILS AND DIKES-Mafic sills and dikes up to $34 \mathrm{ft}(10 \mathrm{~m})$ thick cut stratigraphy throughout map area. Consist of dark brown, pandiomorphic-granular, locally porphyritic basalt, gabbro and diabase. Contains abundant clinopyroxene and lesser olivine biotite, and homblende grains in a plagioclase-rich marrix (An 65). Unit contains three K-Ar mineral ages ranging from 45.5 to 55.0 Ma (Solie and others, 199l).

Tid UNDFFERENTIATED SILLS AND DIKES-Undifferentiated sills and dikes composed of dikes ranging from mafic to felsic compositions. Usually distinguished by extensive alteration and multiple compositions of dikes. Age data summarized above.

Tids DIKE SWARM AND HORNFELS-Large linear zones of muluple dikes of variable composition and size that create extensive homfels aureole and includes fragments of layered country rocks. Includes compositions of dikes described above (Tid, Tim, Tia, Tif). Formation of sulfide skarns evident where swarms intrude calcareous rocks.

Twg WINDY FORK GRANITE-White to pink and locally blue-gray, medium- to coarse-grained, peralkaline arfvedsonite granite of Windy Fork pluxon. Composed of perthite, quanz, and arfvedsonite. and lesser riebeckite. plagioclase, and red-brown biotite. Accessory minerals include zircon, fluorite. apatite, monazite, uranothorite, and eudialyte (Gunter and others, 1993). Has yielded K-Ar pyroxene age of $23.4 \mathrm{Ma}$ and K-Ar biotite and hornblende ages of 30.1 and 29.0 Ma respectively (Gilbert and others. 1988; Solie and others, 1991). Very resistant and forms cliffs, tors, and high upland at the head of Windy Fork. 
Tgd HARTMAN PLUTON GRANODIORITE-Medium- to coarse grained, equigranular, homblende-biolite granodiorite; $\mathrm{CI}=35$ and plagiociase has An 60 composition. A strong homfels aureole up to 1.25 mile $(2 \mathrm{~km})$ wide rings the intrusion. Quartz-sulfide vein stockwork in both homfels and intusion contains molybdenice, chalcopyrite, galena, and abundant pyrite in several localities. One K-As biotite age of $37.9 \mathrm{Ma}$ (Solie and others. 1991) obtained from main intrusion is similar in age to volcanics of Terra Colta volcanic field immediately to the norh, suggesting that volcanics and intrusion may be co-magmatic. Very resistant and forms cliff walls in southern Terra Cona Mountains.

Tqm QUARTZMONZONITE, MONZONITE BRECCLA, AND QUARTZ PORPHYRY-Composise unit of mainly light gray, [ine- to medium-grained hypidiomorphic to equigranular, biotite quartz monzonite, aegirine-rich monzonise. and altered biotite quartz porphyry. Unit Tqm appears as circular to elongate plutons ranging in area from 1.2 square miles $\left(3 \mathrm{~km}^{2}\right)$ in the southem Veleska Lake volcanic fieid to 4.8 square miles $\left(12 \mathrm{~km}^{2}\right)$ in the Post River and Bowser Creek bodies. The Bowser and Veleska Lake intrusions are aligned along an 18 mile $(30 \mathrm{~km})$ long north-trending fault suggesting structural control for emplacement of the plutons. Other smaller bodies in Sheep Creek basin and at Post River show similar norh-south orientations. Strong igneous and sedimentary breccias developed in Bowser Creek and $7205 \mathrm{Mt}$. plutons. Nine K-Ar mineral ages from five Tqm plutons range from 51.1 to $61.8 \mathrm{Ma}$ and average $58.0 \mathrm{Ma}$ (Solie and ouhers, 1991). Polymetallic mineralization associated with Bowser, Veleska Lake, Post, and Sheep Creek plutonic complexes (Bundtzen and others, 1982, 1987; this study). All Tqm bodies are very resistant and form some of the most rugged terrain in study area.

Tgr SOUTH FORK GRANITE-Light gray, pink, medium- to coarse-grained, equigranular, biotite (muscovite) granite that forms small 1.2 square mile $\left(3 \mathrm{~km}^{2}\right)$ body on west side of South Fork flanking Terra Cotta volcanic field. Large poikilitic K-spar grains comprise up to 20 percent of groundmass. East-west rending felsic dikes inerude core of pluton. K-Ar biotite age of $58.8 \mathrm{Ma}$. Nor so resistant; forms subdued rubble.

Thf HORNFELS AND SKARN-Brown to gray, massive 10 locally porphyroblastic, gamet-chlorite-biotite homfels derived from carbonate and clastic rocks. Locally develops into polymetallic skarns containing introduction of gamet, wollastonite, epidote, grossularite, and johannsenite. Largest skam zone surrounding Hartman pluton (Tgd) is 1.3 miles $(2 \mathrm{~km})$ wide, but most are 0.3 miles $(0.5 \mathrm{~km})$ wide or less. Some Thf zones associated with dike swarms are only about $10 \mathrm{fr}(3 \mathrm{~m})$ wide. Age of homfels dependent on age of related intrusion. Generally considered resistant throughout map area, and forms equant blocks.

Middle Fork Plutonic Complex (Solie, 1983, 1988; Gilbert and others, 1988)

Tgqm GRANITE, QUARTZ MONZONITE, AND MONZODIORITE-Fine- to medium-grained, biotite- and homblende-bearing plutonic rocks with variable quartz contents and feldspar ratios: predominantly quartz monzonite and monzodiorite. Plagioclase composition ranges from andesine to labradorite; minor clinopyroxene generally present and rimmed by andesine to labradorite: minor orthopyroxene sometimes present and rimmed by homblende: locally alkali feldspar phenocrysts. Accessory zircon and apatite are common; tourmaline is present locally. Fine-grained mafic enclaves common, some retain layering of sedimentary origin. Three samples of quartz monzonite yielded $\mathrm{K}$-Ar mineral ages of $56.1,56.6$, and $57.2 \mathrm{Ma}$. Eastem margin of the Middle Fork plutonic complex is medium- 10 coarse-grained peralkaline granite very similar in mineralogy 10 Windy Fork granite (Twg) and appears gradational with syenite unit (Tsy below). Eudialyte samples noted in granite calus in two locations. Two samples from the eastem margin granite yielded K-Ar mineral ages of 57.7 and 55.6 Ma. Outcrop typically massive and weather in large blocks.

Tgb ALKAlI GABBRO-Dark green-brown, fine- to medium-grained, biotite-olivine-pyroxene gabbro. Composed of andesine, clinopyroxene, biotite, olivine, and green to brown hornblende after pyroxene. Minor constituents include opaque minerals, alkali feldspar, orthopyroxene, and accessory apatite. Secondary minerals include chlorite, iddingsite, serpentine, actinolite, carbonate, and apophyllite. Gabbro typically weathers to brown grus, which forms rounded outcrops. 
Tgsy GRANITE TO QUARTZ SYENITE-Fine- to coarse-grained, granite to quartz syenite. Contains homblende. clinopyroxene, and biotice, and minor opaque minerals. aparite, and zircon; arfvedsonite and riebeckite present locally. Alkali feldspar generally perthitic and common in hand specimen. Unit typically weathers to white grus.

Tsy SYENITE-Green-gray. white-gray weathering, medium- to coarse-grained, olivine-clinopyroxene syenite: locally iron stained. Composed of perthitic alkali feldspar, green-brown hornblende after pyroxene, clinopyroxene, plagioclase, olivine and magnetite alteration rims, and interstitial quartz. Minor constituents are biotite, opaque minerals, rutile needles, apatite, zircon, fluorite(?), and monazite(?). Secondary minerals include chlorite, carbonate, iddingsite, actinolite, and epidote. Typically forms massive, jointed cliffs.

\section{LATE CRETACEOUS INTRUSIVE ROCKS AND HORNFELS}

TKqm MOUNT ESTELLE GRANODIORITE-Fresh, medium-gray, medium-grained, equigranular, homblendebiotite granodiorite and locally contains plagioclase(?) phenocrysts $105 \mathrm{~mm}$ long. Ar ${ }^{40}$-A ${ }^{99}$ biotite age of 67.4 Ma obtained from pluton in southeast comer of map area.

TKm GABBRO-GRANODIORITE-Heterogeneous dike swarms consisting of augite gabbro, homblende granodiorite, and monzodiorite. Euhedral homblende and piokilitic biotite phenocryses are unusually fresh; unit is not hydrothermally altered like younger Tim dikes in map area. K-As biotite and homblende ages of 69.7 and 79.0 Ma from biotite and homblende, respectively, for small bodies east of South Fork.

TKhf HORNFELS AND SKARN-Brown to gray. massive to locally porphyroblastic, gamet-chlorite-biotite honfels derived from carbonate and clastic rocks. Locally develops into polymetallic skarns with introduction of gamet, wollastonite, epidote, grossularite, and johannsenite. Most homfels are 0.3 miles $(0.5 \mathrm{~km})$ wide or less. Some associated with dike swarms are only a few meters wide. Age of homfels dependent on age of related intrusion. Generally considered resistant throughout map area, and forms equant blocks.

\section{PRE-CRETACEOUS INTRUSIVE ROCKS}

KJg GABBRO AND DIORITE-8uff-weathered, dark green-gray gabbro and diorite that intrude both Upper Paleozoic cherts and volcaniclastic rocks (uPzs) of the Yukon-Tanana terrane and Triassic limestone (Trls) of the Pingston terrane. Although no age control is known, unit may be equivalent to a Jurassic-Cretaceous gabbrodiorite swarm that intrudes along a major suture separating the Pingston Terrane from the Yukon-Tanana tersane in Denali National Park (Jones and others, 1983).

Trum ULTRAMAFIC TO DIORITE SILLS-Dark green-gray, fine- to coarse-grained, ultramafic (picrite and ankaramite) sills, olivine gabbro, and diorite usually 50 to $66 \mathrm{ft}(15$ to $20 \mathrm{~m})$ thick but some thinner intrusions also observed. Sills in Sheep Creek area differentiated into mafic or ultramafic bases and dioritic rops. Locally magnetite so abundant (up to 40 percent) that rocks can be picked up with a magnet. Compositions plot in tholeiitic field. Creates extensive zones of hydrothermal alteration, including carbonate alteration and serpentinization in host Mystic subtertane sedimentary rocks (PDs). No absolute age contsol is available; we envision Trum as feeders for Late Triassic volcanism of Tatina River Volcanics; hence Trum assigned a Late Triassic age. Unit Trum is relatively resistant when fresh but non-resistant when hydrothermally altered.

MzPzi GABBRO AND DIORITE SILS AND DIKES-Brownish weathered, dark green-gray, very fine- to medium-grained phaneritic, locally micropegmatoidal, olivine, aegirine-augite, gabbro, diórite, and uncommonly alkali syenite. Quarz rare or absent. Large olivine and clinoproxene grains to $5 \mathrm{~mm}$ in diameter remarkably fresh, although groundmass ubiquitously aitered. Larger sills create zones of homfels although not depicted on map sheet. Unit is everywhere olivine normative and sometimes nepheline normative and chemically exhibits a tholeiitic, alkaline character. MzPzi exclusively intrudes Lyman Hills Formation (OCls) and Post River Formation (SOsh. ISl) of the Dillinger subtersane, and never younger units. Hence we believe an Early Paleozoic age seems likely. A less plausible alternative is that MzPzi dikes are feeders for Triassic volcanism (Trab) in the Mystic subterrane (Tatina River volcanics). Resistant and forms blocky rubble standing in relief against hos: OCls and SOsh lithologies. 
